This item was submitted to Loughborough's Research Repository by the author.

Items in Figshare are protected by copyright, with all rights reserved, unless otherwise indicated.

\title{
Water disclosure and firm risk: Empirical evidence from highly water- sensitive industries in China
}

PLEASE CITE THE PUBLISHED VERSION

https://doi.org/10.1002/bse.2347

\section{PUBLISHER}

(c) Wiley

VERSION

AM (Accepted Manuscript)

\section{PUBLISHER STATEMENT}

This is the peer reviewed version of the following article: ZENG, H. ... et al, 2019. Water disclosure and firm risk: Empirical evidence from highly water-sensitive industries in China. Business Strategy and the Environment, 29(1), pp. 17-387, which has been published in final form at https://doi.org/10.1002/bse.2347. This article may be used for non-commercial purposes in accordance with Wiley Terms and Conditions for Use of Self-Archived Versions

\section{LICENCE}

CC BY-NC-ND 4.0

\section{REPOSITORY RECORD}

Zeng, Huixiang, Tao Zhang, Zhifang Zhou, Yang Zhao, and Xiaohong Chen. 2019. "Water Disclosure and Firm Risk: Empirical Evidence from Highly Water-sensitive Industries in China”. Loughborough University. https://hdl.handle.net/2134/38232. 


\title{
Water disclosure and firm risk: Empirical evidence from highly water-sensitive industries in China
}

\author{
Huixiang Zeng 1 \\ Tao Zhang 2 \\ Zhifang Zhou 1,3 \\ Yang Zhao ${ }^{2}$ \\ Xiaohong Chen $1,3,4$
}

1 School of Business, Central South University, Changsha, China

2 Institute for Innovation and Entrepreneurship, Loughborough

University London, London, UK

3 Corresponding author

Collaborative Innovation Center of Resource-Conserving and

Environment-Friendly Society and Ecological Civilization, Central South University, Changsha, China

4 Institute of Big Data and Internet Innovation, Hunan University of Technology and Commerce, Changsha, China

Accepted for publication in Business Strategy and the Environment, May 2019 


\title{
Water disclosure and firm risk: Empirical evidence from highly water-sensitive industries in China
}

\begin{abstract}
In this paper, we examine the relationship between water disclosure and firm risk. Specifically, based upon a panel dataset of 334 Chinese listed firms operating in highly water-sensitive industries during 2010-2015, we use regression models to analyze the relationships between water disclosure and three types of firm risk (i.e., total risk, systematic risk, and idiosyncratic risk) and the moderating effects of media coverage on these relationships. Our empirical results show that (a) although there are no significant relationships between water disclosure and total risk and idiosyncratic risk, there is a significant negative relationship between water disclosure and systematic risk; (b) negative media coverage weakens the negative relationship between water disclosure and systematic risk, whereas nonnegative media coverage reinforces this negative relationship. Our cornerstone study examines the effect of a specific type of environmental disclosure (i.e., water disclosure) on firm risk, and our empirical findings are different from previous studies, which examined the effects of overall corporate social responsibility (CSR) disclosure on firm risk. We analyze the causes of the differences in detail. With this study, we make theoretical, empirical, and managerial contributions to CSR disclosure-firm risk research in business ethics literature.
\end{abstract}

\section{KEYWORDS}

Firm risk, media coverage, media valence, water disclosure

\section{INTRODUCTION}

Water is the cradle of life on the earth. Approximately $70 \%$ of the earth's surface is covered by water. Although at a glance of this figure, it looks like water is abundant 
on the earth, actually it is scarce. Due to the growing world's population, it has been forecasted that global demand for clean water will exceed the available supply by $40 \%$ by 2030 (CEO Water Mandate, 2008). Water shortage will be one of the toughest challenges to the global economy (CDP, 2015). In addition to water shortage, other water problems (e.g., water depletion and pollution) caused by the worldwide urbanization and industrialization have also become prominent issues globally. These water problems can significant affect the sustainable development of human society.

Firms produce the world's most primary goods to satisfy human needs, and they are also the major consumers of freshwater (Burritt \& Christ, 2018). It is significantly important for firms to improve their water management practice and enhance the transparency of the information about their water utilization (Hurlimann \& Dolnicar, 2012; Jones, Hillier, \& Comfort, 2015). Therefore, firms' water disclosure is an important firm level business ethics issue. However, one fact in the current business ethics literature is that corporate water disclosure has received little research attention.

Traditional disclosure research in business ethics literature often examines the relationship between overall corporate social responsibility (CSR) disclosure (i.e., overall environmental and social disclosures) and firm risk (e.g., Benlemlih, Shaukat, Qiu, \& Trojanowski, 2016; Jo \& Na, 2012). Although these prior studies contribute significantly to the CSR disclosure-firm risk type of research, they raise some interesting questions.

First, the measures of environmental (E) and social (S) disclosures are composite indicators covering multiple types of environmental and social disclosures based on the Global Reporting Initiative frame- work, for example, carbon (and other types of greenhouse gases (GHGs)) emissions, energy consumption, water management, and waste management. Although such composite indicators can effectively measure the overall environmental and social disclosures of a firm, they cannot reveal whether and how a specific type of disclosure (e.g., in our case, water disclosure) can affect firm risk. Such insights are practically useful because firms of different industries may have their own preference in terms of disclosure types and place different levels of importance on different types of environ- mental disclosures. Enabling them to 
understand whether and how a particular type of environmental disclosure can affect their risk would enable them to make more effective disclosure decisions. Such insights are academically desirable, as different types of disclosures can have different theoretical mechanisms to affect firm risk. Exploring these theoretical mechanisms and empirically testing them offer opportunities to make further developments in CSR disclosure- firm risk research.

Second, prior studies directly test the relationship between CSR disclosure and firm risk without considering the moderating factors. In today's business environment, the relationship between $\mathrm{E}$ and $\mathrm{S}$ dis- closures and firm risk can be influenced by a lot of contingency factors, for example, market-level legislative or regulatory power such as mandatory or voluntary disclosure regime, or society-level media coverage. From a market point of view, in today's business climate stakeholders (especially shareholders, the government and consumers) are highly concerned with firms' environmental performance. Voluntarily disclosing high-quality environmental information beyond legal requirements can lessen the information asymmetry between a firm and its stakeholders, thus alleviating the stakeholder pressure that the firm is facing, which in turn reduce the firm's market risks (Gallego-Alvarez, Ortas, Vicente-Villardón, \& Álvarez Etxeberria, 2017). From a society point of view, media coverage can disseminate and interpret information and shape public opinions. Thus, it has significant effect on corporate environmental responsibilities and the capital market. Hurlimann and Dolnicar (2012) suggested that media coverage (including media attention and the valence of voice) would affect firms' water-related behavior and attitudes. We therefore argue that understanding the moderating effects of these contingency factors on the relationship will give stakeholders useful strategy implications in a specific context.

Third, prior CSR disclosure-firm risk research primarily focused on western developed countries such as the United States (Jo \& Na, 2012) and the United Kingdom (Benlemlih et al., 2016). As suggested by Gallego-Alvarez et al. (2017), firms operating within the codified law countries are more inclined to focus on water and emissions in their environmental reporting, whereas firms operating within the 
common law countries show more interest in materials and energy issues in their environmental reporting. Moreover, Ben-Amar and Chelli (2018) revealed that country-level legal systems affected firms' propensity to voluntarily respond to the 2015 Carbon Disclosure Project survey. Therefore, the institutional and business regulatory frameworks in different country can significantly influence firms' environmental reporting and risk-related outcomes. It would be helpful to extend the research to other countries where the institutional and business regulatory frameworks are different from those in the countries included in prior studies to examine the generalizability of prior findings.

These interesting questions have motivated us to carry out further study to examine relationship between a particular type of environ- mental disclosure and firm risk involving moderating effects using high-resolution data in a different empirical setting. Given the importance of water disclosure and the fact that it has received little research attention in business ethics literature, we examine its effect on firm risk using 334 Chinese listed companies operating in highly water-sensitive industries (i.e., companies/industries that both utilize and impact water resources in a significant way) during 2010-2015. We look at China because it is the largest emerging economy and the second largest economy in the world. China's water sustainability can affect the sustainable development of the world as a whole. As noted in an article highlighted in Science (Liu \& Yang, 2012, p. 649), "water problems are particularly challenging in China, which has the largest population, fastest-growing economy, rising water demand, relatively scarce water, dated infrastructure, and inadequate governance." However, a reality in China is that many Chinese firms lack the awareness of water problems - only $38 \%$ of Chinese listed firms currently disclose their total water consumption (CDP, 2016). Additionally, the institutional framework in China is unique around the world - it has a well-mixed economy comprising state-owned and nonstate-owned firms. Therefore, China presents an ideal empirical setting for examining the water disclosure and firm risk relationship. Furthermore, considering the fact that firms' environment and social disclosures can be influenced by media coverage (Brown \& Deegan, 1998; Islam \& Deegan, 2010), we integrate media 
coverage in the study as a factor moderating the water disclosure and firm risk relationship. Interestingly, our empirical findings are different from prior research examining the relationship between overall CSR disclosure and firm risk (e.g., Benlemlih et al., 2016). Although we have not found any relationship between water disclosure and total risk (hereafter, WD-TR) and idiosyncratic risk (hereafter, WDIR), we have found a significant negative relationship between water disclosure and systematic risk (hereafter, WD-SR). In so doing, we make the following contributions

1. Compared with prior studies in this field (e.g., Benlemlih et al., 2016; Jo \& Na, 2012), we make a significant step forward in CSR disclosure-firm risk research by examining the relationship between a specific type of environmental disclosure (i.e., water disclosure) and firm risk involving moderating effects in a novel empirical setting. This from "general" to "specific" move offers brand new theoretical insights about CSR disclosure-firm risk research. We provide new theoretical arguments about how water disclosure can influence firms' systematic risk and idiosyncratic risk, and how media coverage can moderate the influence. A panel dataset of 334 Chinese listed companies operating in highly watersensitive industries during 2010-2015 has been employed to empirically test these new theoretical insights. We also discuss why our results are different from those in prior studies. These theoretical and empirical contributions are a significant development in CSR disclosure-firm risk research in business ethics literature.

2. We extend the "water disclosure index" by developing a novel index system to measure the degree of water disclosure of Chinese firms. The state of the art of water disclosure measures includes two systems: "whether to respond to CDP's water information questionnaire or not" (Zhang \& Tang, 2015) and the "water disclosure index" (Burritt, Christ, \& Omori, 2016). Based on the two systems and drawing on previous research about environmental disclosure and carbon disclosure (Alrazi, de Villiers, \& Van Staden, 2016; Luo \& Tang, 2014), we develop a novel water disclosure measurement scale composed of qualitative and 
quantitative indicators. This makes a methodological contribution to CSR disclosure research.

3. We analyze the interactive mechanisms among water disclosure, media coverage, and firm risk, which offers managerial implications for firms to leverage their key resources for risk control. This makes practical contributions to support the continuous efforts to develop sustainable business strategies.

The remainder of the paper is arranged as follows. Section 2 reviews relevant literature and develops the research hypotheses. Section 3 introduces the research design and methods. Section 4 describes the empirical results. Section 5 discusses the results and concludes the paper.

\section{LITERATURE REVIEW AND RESEARCH HYPOTHESES}

\section{Water disclosure}

Water disclosure refers to the information that a firm reports to its stakeholders about the current situation of its water resource management, including how it implements its water resource management strategy, the impact of this strategy on its business, and other aspects (CEO Water Mandate, 2014). The purpose of corporate water disclosure is to provide useful monetary or other quantitative information related to corporate water management activities to stakeholders.

In recent years, water disclosure has received increasing attention from both industry and academia. Industry wise, the Pacific Institute called on firms to disclose water information in 2007; the CEO Water Mandate (2008), CDP (2010), and other business/nongovernmental organizations made substantial progress in water disclosure; and the Corporate Water Disclosure Guidelines gives firms guidance for their water disclosure practice (CEO Water Mandate, 2014). Some companies have realized the importance of water disclosure and started to respond positively to these efforts. Academia wise, extant literature has embedded water disclosure into CSR reporting from the perspectives of (a) economics (welfare; Hazelton, 2014; Martinez, 
2015); (b) firm strategies for handling water resources (Barber \& Jackson, 2012; Kurland \& Zell, 2010); and (c) the accounting of the value of water resources (Egan, 2014; Signori \& Bodino, 2013). Compared with the number of studies focusing on general corporate environmental disclosure (e.g., Benlemlih et al., 2016; Huang \& Chen, 2015), the number of studies specifically focusing on water disclosure is very limited. Literature search only identifies a few studies beyond business ethics literature, for example, Rajput, Kaura, and Khanna (2013) first introduced the concept of water disclosure; Dennis, Connole, and Kraut (2015) investigated how watersensitive companies in the mining industry did water disclosure under the Global Reporting Initiative G3 reporting framework, and the authors found that there was a lack of completeness in water disclosures; Botha and Middelberg (2016) studied the adequacy of water-related disclosure of high-impact firms in South Africa and suggested that an improved water disclosure index or standard should be developed and applied. In a recent empirical study using a sample of 100 Japanese listed companies, Burritt et al. (2016) identified some significant drivers of water disclosure: company size, water sensitivity, and ownership concentration. Thus, water disclosure research is still in its infancy and requires both theoretical and empirical developments.

\section{Research hypothesis development}

\section{Water disclosure and systematic risk: A negative relationship}

Firms' total risk is a risk "inherent in a firm's operations as a result of external or internal factors that can affect the firm's profitability" (Jo \& Na, 2012, p. 441). Firm's total risk is a combination of systematic risk and idiosyncratic risk, and it is often reflected by stock price volatility (Jo \& Na, 2012; Luo \& Bhattacharya, 2009). Although systematic risk is triggered by external macrolevel factors such as market or economic conditions, idiosyncratic risk is triggered by internal firm- specific factors.

Systematic risk (also known as "market risk"), which cannot be dispersed and eliminated, is mostly caused by the external economic/market conditions. Extant literature discussing the relation- ship between CSR and systematic risk was mainly 
from the perspectives of agency theory, stakeholder theory, and information asymmetry theory. (Benlemlih et al., 2016; Beyer \& Guttman, 2012; Cai, Cui, \& Jo, 2016). These theories take the economic assumption that the decision makers of corporate disclosures are economically rational agents that seek to maximize their economic benefits or utility. However, this economic assumption ignores the effects of institutional context and organizational legitimacy on the decision makers of corporate disclosures (DiMaggio \& Powell, 1983). Institutionalism theory and the theory of organizational legitimacy, which explains economic phenomena from social perspectives, can address this limitation and provide alternative theoretical mechanisms to under- stand the relationship between corporate environmental disclosure and systematic risk.

According to institutionalism theory, firms can be influenced by the norms in an industry, and these industrial norms are a part of institutional pressure which forces firms to imitate each other (Li, Fu, \& Gao, 2016; Poisson-de Haro \& Bitektine, 2015). Whether firms make environmental disclosures is decided by the coercive pressure (i.e., normative isomorphism), but the level of environmental disclosure they make is the result of their imitation (i.e., mimetic isomorphism), that is, firms tend to imitate best practice in an industry (DiMaggio \& Powell, 1983). Aerts, Cormier, and Magnan (2006) used institutional- ism theory to explain firm environmental disclosure and examined the institutional factors that lead to firms' imitation of environmental disclosure. Water disclosure is a type of environmental disclosure. Therefore, according to institutionalism theory, we argue that whether firms disclose their environmental information is determined by institutional normative pressure, and the amount of water information they disclose is determined by their imitation behavior.

Further, the theory of organizational legitimacy explains the motivation and consequences of firms' imitation behavior. Legitimacy is a type of organizational resource, which can demonstrate that the value of a firm is in line with that of the society (Mahadeo, Oogarah- Hanuman, \& Soobaroyen, 2011). New institutionalism examines the importance of organizational legitimacy and suggests that firm imitation behavior is an important means for firms to gain legitimacy and reduce uncertainty. 
Firms with best practices initiate the signal of legitimacy, and other firms copy this practice; when a large number of firms adopt a practice, the legitimacy of the practice can be enhanced and firms can face a lower level of market risk (Bansal \& Clelland, 2004; Lieberman \& Asaba, 2006). Gaining legitimacy is a motive for firms to engage in environmental activities (Tilling \& Tilt, 2010). Disclosing environmental information according to the best practice in the industry serves as a tool of legitimacy (Cho \& Patten, 2007). Water disclosure, as a type of environmental disclosures, can enable all firms to gain legitimacy. Firms with high-quality water disclosure can initiate the signal of legitimacy, therefore gaining strong recognition from wider stakeholders. Other firms copy this water dis- closure behavior. When there is a sufficiently large number of firms copy water disclosure behavior, water disclosure becomes a norm in the market, which can improve the stability of the market, therefore helping firms access more resources, enhance their market value, lessen their capital costs and market uncertainties, ultimately reducing their market risk (Certo \& Hodge, 2007; Delgado-García, de Quevedo- Puente, \& Díez-Esteban, 2013; Qiu, Shaukat, \& Tharyan, 2016).

Empirically, although there are few studies exploring the direct effect of water disclosure on firms' systematic risk, studies of corporate environmental and social performance/disclosure and firms' systematic risk provide us with some insights. Performance wise, it is generally recognized that corporate social performance can help firms reduce systematic risk, although the extent of this effect is controversial. Salama, Anderson, and Toms (2011) conducted an empirical study using data in the United Kingdom covering the period 1994-2006 and found a weak negative relationship between corporate social performance and systematic risk. Oikonomou, Brooks, and Pavelin (2012) and Cai et al. (2016) conducted empirical tests using U.S. companies as samples and came to the same conclusion - a weak negative relationship. Although there are continuing debates about the relationship between corporate environmental performance and disclosure (see Cho \& Patten, 2007), much empirical evidence supports the view that there is a positive correlation between the two, especially in environment-sensitive industries (e.g., Al-Tuwaijri, Christensen, \& 
Hughes, 2004; Clarkson, Li, Richardson, \& Vasvari, 2008). Therefore, we argue that in water-sensitive industries, high-quality water disclosure reflects high-quality water performance, which weakens firms' systematic risk. Disclosure wise, Orlitzky and Benjamin (2001) and Jo and $\mathrm{Na}$ (2012) agreed that corporate environmental/social disclosure is significantly negatively related to systematic risk. More interestingly, Benlemlih et al. (2016) came to the distinct conclusion that extensive and objective environmental and social disclosure will increase firms' market value, but it will not reduce their systematic risk. In summary, although empirical findings about the relationship between environmental/social disclosure and firms' systematic risk are some- what controversial, the negative correlation between environmental disclosure and systematic risk has been widely accepted. Water information is an important piece of environmental information, and improving water disclosure is an important initiative for the improvement of corporate environmental information transparency and the strengthening of CSR (CEO Water Mandate, 2014; Schembera, 2016).

In the light of the above theoretical arguments and drawing on the empirical evidence from prior relevant studies, we develop the following hypothesis:

Hypothesis 1a. Water disclosure is negatively related to a firm's systematic risk.

\section{Water disclosure and idiosyncratic risk: A negative relationship}

Idiosyncratic risk is a firm's unique risk, which has nothing to do with market volatility and only affects the firm individually. Prior studies (e.g., Benlemlih et al., 2016; Oikonomou et al., 2012; Orlitzky \& Benja- min, 2001; Salama et al., 2011) explained the relationship between CSR disclosure and idiosyncratic risk using agency theory and stake- holder theory. In our study, we provide alternative theoretical explanations of the WD-IR relationship using reputation theory and signaling theory.

According to reputation theory, reputation is an important type of intangible assets of a firm; it not only reflects public perception and recognition of the firm's past performance but also demonstrates the firm's value from multiple perspectives (Fombrun \& Shanley, 1990). Maignana and Ferrell (2003) and Delgado-García et al. 
(2013) summarized different types of firm reputation and pointed out that CSR is an essential element of and an important measure of corporate reputation. Particularly under the circumstance where global environmental issues become severer, firms' environmental awareness and activities have attracted much public attention. Voluntarily disclosing environ- mental information in a firm's annual financial reports, CSR reports and/or sustainability reports can demonstrate the firm's willingness to undertake its environmental responsibility (Fombrun, 1998; Starr, 2016). These voluntary disclosures are a strategic choice for improving firms' reputation in a society.

In many developing countries, corporate environmental disclosures (including water disclosure) are still voluntary, not a regulatory requirement. Nonetheless, based on signaling theory, firms still have the motivation to disclose their environmental information in order to distinguish themselves from those who have poor environmental performance and enable stakeholders to gain real information for decision making, which can foster better business opportunities and build more reputation capital (Dawkins \& Fraas, 2011). Therefore, water disclosure is an effective means for firms to gain more reputation capital, which in turn can build trust between firms and their stakeholders, lower transaction costs, reduce uncertainties, and decrease information asymmetry. Fombrun and Rindova (1996) suggested that reputation capital is a unique advantage for firms to deal with risks. Firms' idiosyncratic risks are spreadable. Thus, firms can gain more reputation capital to spread/reduce their idiosyncratic risks through active water disclosure (Hasseldine, Salama, \& Toms, 2007).

In the literature, there are no empirical studies examining the direct effect of water disclosure on firms' idiosyncratic risks. Kurland and Zell (2010) analyzed 135 papers related to water that were published in the top 49 business journals and found that water constraints will lead to an increase in production costs, damage to brand image, and possibly even cause some firms to lose their business licenses. Thus, responsible water utilization and water information transparency can reduce these firm-specific risks. In addition, empirical studies of the relationship between 
corporate environmental disclosure/performance ${ }^{1}$ and firm risks can give us some inspiration. Jo and $\mathrm{Na}$ (2012) and Oikonomou et al. (2012) found that CSR performance is negatively related to corporate financial risk, and Cai et al. (2016) drew the same conclusion after controlling for firm het- erogeneity. From the perspective of risk aversion, Li, Eddie, and Liu (2014) found that CSR disclosure helps to attract customers, reduce resistance to entering into the capital market, and is an effective way to reduce firms' idiosyncratic risks. Cheung (2016) examined the effectiveness of CSR reports from the perspective of cash holdings and found that firms with CSR disclosure usually have low cash holdings because of their low idiosyncratic risk. Birkey, Michelon, Patten, and Sankara (2016) confirmed that the higher the score of environmental disclosure, the better the firm's environment reputation (which is one effective means to reduce idiosyncratic risk). Water disclosure is an important type of firms' environmental disclosures. Based on the above theoretical discussions and empirical findings, we infer that water disclosure can also help to control idiosyncratic risk. Thus,

Hypothesis 1b. Water disclosure is negatively related to a firm's idiosyncratic risk.

As firms' total risk is a combination of systematic risk and idiosyncratic risk (Jo $\& \mathrm{Na}, 2012), 1 \mathrm{a}$ and $1 \mathrm{~b}$ lead to the following overall hypothesis:

Hypothesis 1. Water disclosure is negatively related to a firm's total risk.

\section{Moderating effect of media coverage}

The media is one type of the stakeholders that are involved in firms' development in the business environment (Mitchell, Agle, \& Wood, 1997). Media outlets can expand the information dissemination, lower external investors' cost of information collection, and reduce their information risk (Bushee, Core, Guay, \& Hamm, 2010). According to signal transmission theory, media coverage can reduce information

\footnotetext{
${ }^{1}$ We again hold the view that there is a positive correlation between disclosure and performance.
} 
asymmetry in the capital market via its "information intermediary" and "external disciplining" functions (Spence, 1973; Tetlock, 2011). Media coverage can improve the transparency of firms' information disclosures and affect investors' understanding of the market and their investment behavior (Cahan, Chen, Chen, \& Nguyen, 2015). Thus, the "external disciplining" effect of the media can complement the underdeveloped regulatory systems in emerging capital markets such as China.

We discuss the moderating effect of media coverage on the relationship between water disclosure and firm risk using agenda-setting theory, which suggest that the media has the ability to influence the salience of topics on the public agenda (McCombs, Shaw, \& Weaver, 2014). According to agenda-setting theory, the more frequently and prominently a news item is covered by the media, the more important it would be regarded as by the public (McCombs \& Shaw, 1972). Essentially, there are two prominent effects of the media on the public, that is, priming public opinion, and affecting the public's attitudes toward social issues (i.e., attribute agenda-setting). Both effects demonstrate that "closer attention to the specific content of mass media messages - including the tone of those messages - provides a more detailed understanding of the pictures in our heads and of subsequent attitudes and opinions grounded in those pictures" (McCombs, 2000, p. 14). Therefore, the tone, or valence, a technical term indicating to what extent the news item is positive, neutral, or negative, can largely affect the public's attitudes and opinions toward social issues. In capital markets, media valence can cause investors' judgment deviation and sentiments, which in turn influence investment behavior (Kölbel, Busch, \& Jancso, 2017; Wang \& Ye, 2015). Based on a media coverage and firm valuation study by Wang and Ye (2015), we distinguish two types of media valence: nonnegative (i.e., positive and neutral) and negative. From firms' perspective, nonnegative media coverage about their environmental responsibilities can help them establish good reputation and build trust with customers and investors, thus improving their financing capacity and reducing their risks (Liu \& McConnell, 2013). From external stakeholders' perspective, nonnegative media coverage about firms' environmental responsibilities can help them gain real information about firms' environmental 
performance, based upon which they can exert influence on firms' operations, thus reducing the risks related to firms' operations, management, and so forth (Hurlimann \& Dolnicar, 2012). Negative media coverage, on the contrary, can damage firms' reputational capital and legitimacy (Pollock \& Rindova, 2003) and reduce firms' profitability (Gurun \& Butler, 2012), therefore causing higher risks for firms. Although previously there were no studies looking at the moderating effect of media coverage on the relationship between water disclosure and firm risk, we believe that on the basis agenda-setting theory, both nonnegative and negative media coverage would make environmental topics (including water issues) salient in the public; once the public are highly concerned with water issues and they trust/distrust the firms' with high/low reputational capital, any water information disclosed by these firms would be highly weighed by stakeholders in the market; therefore, nonnegative/negative media coverage can reinforce/weaken the relationship between water disclosure and firm risk.

Prior empirical studies on similar topics, for example, Wei, Wang, Fan, and Zhang (2013) and Cahan et al. (2015), showed that stake- holders can exert their influence on firms through media coverage of firms' environmental issues.

Zyglidopoulos, Georgiadis, Carroll, and Siegel (2012) suggested that media coverage can increase CSR. Some other studies found that media coverage plays moderating roles on the relationships between firms' environmental (and social) disclosures and productivity, performance, value, reputational risks, and so forth (Bushee et al., 2010; Cahan et al., 2015). A most recent study, for example, Kölbel et al. (2017), found that media coverage of corporate social irresponsibility is positively related to firms' financial risk by providing conditions that increase the potential for stake- holder sanctions.

In the light of the above theoretical discussions and indirect empirical evidence, we develop the following hypotheses:

Hypothesis 2a. Negative media coverage negatively moderates the relationship between water disclosure and firm risk (including total, systematic, and idiosyncratic risks). 
Hypothesis $\mathbf{2 b}$. Nonnegative (i.e., positive and neutral) media coverage positively moderates the relationship between water disclosure and firm risk (including total, systematic, and idiosyncratic risks).

Figure 1 summarizes the conceptual model to be tested in this paper.

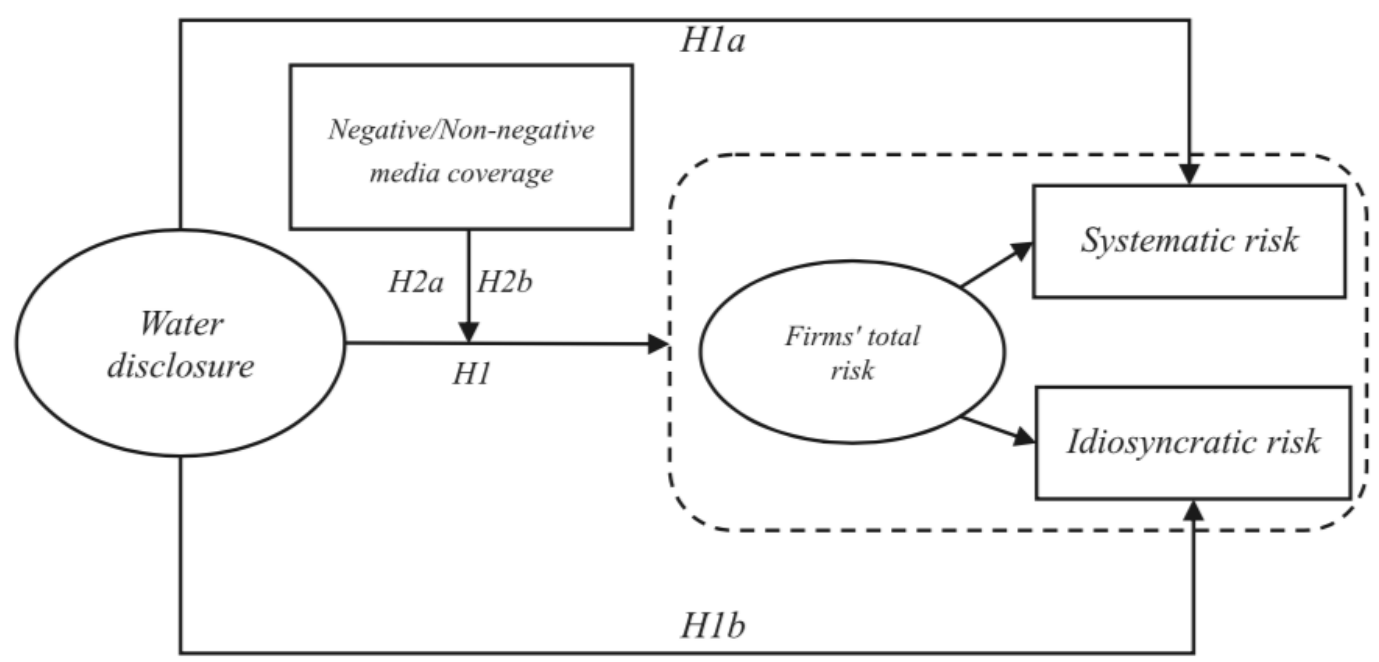

FIGURE 1 Conceptual model with hypotheses

\section{RESEARCH DESGIN}

\section{Sample and data}

We look at the division of each industry's water risk level in the Corporate Water Disclosure Guidelines (CEO Water Mandate, 2014), in con- junction with the Industry Classification Guidance of Listed Companies (2012 edition), and then choose the Chinese A-share listed companies that are recognized as water-intensive and high water risk industries as our sample. These companies can be sorted into five main categories: (a) farming, forestry, animal husbandry, and fishery; (b) mining; (c) manufacturing; (d) electricity, heat, gas, and water production and supply; and (e) water conservancy, environment, and public facilities management. China has been disclosing The Corporate Social Responsibility Report, Enterprise Sustainable Development Report, and Enterprise Environmental Impact Annual Report since 2010; therefore, the time frame of data is 2010-2015. Based on this, we remove firms in our sample according to the following steps: (a) *ST and ST companies; (b) 
companies with financial data missing; and (c) companies with incomplete CSR and CER information. Ultimately, we identify a sample of 334 firms, as shown in Table 1.

The data sources for all variables are as follows: (a) the financial data comes from RESSET database and CSMAR database; (b) firms' water disclosure data comes from The Corporate Annual Report (CNINFO, http://www.cninfo.com/), The Corporate Social Responsibility Report, Environmental Impact Annual Report, and Enterprise Sustainable Development Report (HEXUN, http://www.hexun.com/); and (c) media coverage data comes from the CNKI full-text database of important Chinese newspapers and the Baidu news database (http://news.baidu.com/). We analyze data using Stata14.0 and SPSS19.

TABLE 1 Sample filtering and industry distribution of the sample

\begin{tabular}{|c|c|c|c|c|c|}
\hline Sample filtering & $N$ & Industry & Code & $N$ & Percentage \\
\hline Initial sample & 1,114 & Farming, forestry, animal husbandry, and fishery & $\begin{array}{l}\text { A01- } \\
\text { A04 }\end{array}$ & 5 & 1.50 \\
\hline •ST and ST companies & (103) & Mining & B07 & 3 & 0.90 \\
\hline Companies with financial data missing & (159) & Manufacturing & $\begin{array}{l}\text { C13- } \\
\text { C41 }\end{array}$ & 287 & 85.93 \\
\hline $\begin{array}{l}\text { Companies with incomplete CSR and CER } \\
\text { information }\end{array}$ & (518) & Electricity, heat, gas, and water production and supply & $\begin{array}{l}\text { D44- } \\
\text { D46 }\end{array}$ & 34 & 10.18 \\
\hline- & - & $\begin{array}{l}\text { Water conservancy and environment and public facilities } \\
\text { management }\end{array}$ & $\begin{array}{l}\text { N76- } \\
\text { N78 }\end{array}$ & 5 & 1.50 \\
\hline Final sample & 334 & Total & & 334 & 100 \\
\hline
\end{tabular}

\section{Variable measures}

\section{Water disclosure index}

Water disclosure is the core independent variable in this paper. In order to reflect the level of water disclosure of listed companies comprehensively, we construct a water disclosure index scale (see Data S1) on the basis of previous studies (Burritt et al., 2016; Morikawa, Morrison, \& Gleick, 2007). Specifically, Burritt et al. (2016) improved the water disclosure indicator system (including 24 items) based on Morikawa et al. (2007). We further improve water-related disclosure parameters in Burritt et al. (2016) according to the actual water disclosure situation in China. Our scale consists of a qualitative index (15) and a quantitative index (12), with a total of 
27 indicators. If a firm dis- closes one project, we record "1"; otherwise, we record " 0 ." So the range of each firm's annual score is $Z[0,27], Z=N$.

Due to the large sample size, we use NVivo11 to query and collect data according to the given keywords of each item. Taking the item A1 (see Data S1) as an example, we first search for the key- word "water resource conditions" in each sample firm's annual financial report, CSR report and/or sustainability report. Then, according to the context in which the keyword is located, we judge whether it really involves the expression of water resource conditions in the region where the firm is located, and finally determine whether the score is 1 or 0 . In order to test the validity of the "water disclosure index scale," we refer to Li, Huang, Ren, Chen, and Ning (2016) to analyze the reliability of the water disclosure index. Specifically, we sort the samples according to firm size (as of the end of 2015) from large to small, and choose the top $10 \%$ firms (33) as the subsample; then, we use artificial scoring and software scoring to count the water disclosure scores. When comparing the reliability of the results of the two groups, we find that the correlation coefficient of the two groups is 0.968 , which indicates that the water disclosure index has good consistency and reliability.

\section{Firm risk}

Firm risk is the dependent variable. A firm can be regarded as a series of investment projects (Ljungqvist, Zhang, \& Zuo, 2016), and total investment risk is usually measured by the variance or standard deviation of earnings (Ross, Westerfield, \& Jordan, 2011). The volatility of stock returns is often used to measure a firm's total risk. In this paper, we measure a firm's total risk using the standard deviation of its daily stock returns. However, financial theories hold the view that a firm's total risk consists of idiosyncratic risk and systematic risk. Therefore, we use the Beta coefficient of the capital asset pricing model (CAPM) to measure the systematic risk, because CAPM asserts hat systematic risk can be monetized. As shown in formula (1), the beta coefficient is obtained by regression estimates of daily stock returns and market returns. 


$$
R_{i t}=\alpha_{i}+\beta_{i} R_{m t}+\varepsilon_{i},
$$

where $\mathrm{R}_{\mathrm{it}}$ is the return on security $\mathrm{i}$ for day $\mathrm{t}, \mathrm{R}_{\mathrm{mt}}$ is the return on the market $\mathrm{m}$ for day $\mathrm{t} ; \beta_{\mathrm{i}}$ is the systematic risk of security $\mathrm{i}$ (beta); $\alpha_{\mathrm{i}}$ is the intercept term; and $\varepsilon_{\mathrm{i}}$ is the error term.

In addition, Lee and Faff (2009) and Duan, Hu, and McLean (2010) suggested that idiosyncratic risk is the biggest obstacle to market efficiency. Therefore, we measure a firm's idiosyncratic risk using the standard deviation $(\sigma)$ of residuals $\left(\varepsilon_{i}\right)$ from CAPM based on daily stock return (see Benlemlih et al., 2016) as shown formula (2):

$$
\sigma=\sqrt{\frac{\sum_{i=1}^{n}\left[\left(R_{i t}-\widehat{R_{i t}}\right)-E\left(R_{i t}-\widehat{R_{i t}}\right)\right]^{2}}{n-1}} .
$$

\section{Media coverage}

Media coverage is the moderating factor which includes two variables: nonnegative coverage and negative media coverage. Referring to Wang and Ye (2015), we use the following steps to develop measures for nonnegative coverage and negative media coverage.

1. Identifying the total number of news items about a firm. The frequency that a firm's name appears in news items is a popular way to measure overage (Fang \& Peress, 2009), but the data based only on newspaper reports may underestimate the influence of the Internet. According to the China Internet Development Statistics Report, China's internet users in 2015 reached 649 mil- lion, and the Internet has become an important type of communication media. In this paper, we consider both newspaper and the Internet. We use topic searches to collect the number of news items. The news items that are unrelated to the firms' environmental issues are excluded from our study. We find 50,179 newspaper reports and 74,558 internet reports about our sample firms during 2010-2015. It should be noted that the more times a piece of news is reprinted, the higher the 
level of interest in that news item. We therefore do not remove reprints of the same news item.

2. Counting the number of nonnegative and negative news items about the firm. In order to get the measures of nonnegative coverage and negative media coverage, we subdivide the valence of the news items (nonnegative media coverage vs. negative media coverage) through a content analysis method. Dawning on Wang and Ye (2015), we request two raters to read, code, and classify the valence each news item as nonnegative and negative independently. When there is a disagreement between the two raters, a third rater is invited to discuss this with the two raters and make the final decision. To avoid magnitude interference, we treat the number of nonnegative and negative news items logarithmically (natural logarithm of " $1+$ the number of nonnegative/negative news items").

TABLE 2 Variable definition and measurement

\begin{tabular}{|c|c|c|}
\hline Variable type & Variables & Definition and measurement \\
\hline $\begin{array}{r}\text { Dependent } \\
\text { variables }\end{array}$ & $\begin{array}{l}\text { Volatility } \\
\text { Beta } \\
\text { Idiosyncratic }\end{array}$ & $\begin{array}{l}\text { Total risk, the standard deviation of daily stock returns in current year } \\
\text { Systematic risk, measured by formula (1) } \\
\text { Idiosyncratic risk, measured by formula ( } 2 \text { ) }\end{array}$ \\
\hline $\begin{array}{c}\text { Independent } \\
\text { variables }\end{array}$ & $\begin{array}{l}\text { Water_Disc } \\
\text { Media_Neg } \\
\text { Media_Noneg } \\
\text { Media_News_Neg } \\
\text { Media_News_Noneg } \\
\text { Media_Net_Neg } \\
\text { Media_Net_Noneg }\end{array}$ & $\begin{array}{l}\text { Water disclosure, measured by water disclosure index scale } \\
\text { The sum of newspaper and the Internet's negative coverage, measured by } \operatorname{Ln}(1+n) \\
\text { The sum of newspaper and the Internet's nonnegative coverage, measured by } \operatorname{Ln}(1+n) \\
\text { Newspaper negative coverage, measured by } \operatorname{Ln}(1+n) \\
\text { Newspaper nonnegative coverage, measured by } \operatorname{Ln}(1+n) \\
\text { Internet negative coverage, measured by } \operatorname{Ln}(1+n) \\
\text { Internet nonnegative coverage, measured by } \operatorname{Ln}(1+n)\end{array}$ \\
\hline Control variables & $\begin{array}{l}\text { MTB } \\
\text { SIZE } \\
\text { LEV } \\
\text { ROA } \\
\text { SALEG } \\
\text { CAPXR } \\
\text { OCFR } \\
\text { ADVR } \\
\text { STATE } \\
\text { YEAR } \\
\text { IND }\end{array}$ & $\begin{array}{l}\text { Market value of assets/book value of assets } \\
\text { Ln (total assets) } \\
\text { Book value of debt/total assets } \\
\text { (Net incomes/average total assets) } * 100 \% \\
\text { (Sales incomes in year } t / \text { sales incomes in year } t-1) * 100 \% \\
(\text { Capital expenditure expense/average total assets) } * 100 \% \\
(\text { Operating cash flows/average total assets) } * 100 \% \\
\text { (Advertising expense/total operating incomes) } * 100 \% \\
\text { Dummy variable, equaling } 1 \text { for central state-owned enterprises, equaling } 2 \text { for local state-owned enterprises } \\
\text { and } 0 \text { otherwise } \\
\text { Dummy variable } \\
\text { Dummy variable }\end{array}$ \\
\hline
\end{tabular}


TABLE 3 Descriptive statistics

\begin{tabular}{|c|c|c|c|c|c|c|}
\hline Variables & Observation & $M$ & Median & $S D$ & Min & Max \\
\hline Volatility & 2,004 & 0.0279 & 0.0259 & 0.0098 & 0.0080 & 0.2078 \\
\hline Beta & 2,004 & 1.0445 & 1.0525 & 0.2652 & 0.0487 & 2.6161 \\
\hline Idiosyncratic & 2,004 & 0.1592 & 0.1110 & 0.1762 & 0.0001 & 3.7467 \\
\hline Water_Disc & 2,004 & 6.9586 & 7 & 1.9667 & 2 & 15 \\
\hline Media_Neg & 2,004 & 1.5040 & 1.3863 & 0.5619 & 0 & 4.1271 \\
\hline Media_Noneg & 2,004 & 3.8525 & 3.7377 & 0.5431 & 0.6931 & 6.3969 \\
\hline Media_News_Neg & 2,004 & 0.5491 & 0 & 0.7808 & 0 & 4.1109 \\
\hline Media_News_Noneg & 2,004 & 2.0171 & 1.7918 & 1.5059 & 0 & 6.3526 \\
\hline Media_Net_Neg & 2,004 & 1.5004 & 1.3863 & 0.3169 & 0.6931 & 3.2581 \\
\hline Media_Net_Noneg & 2,004 & 3.5074 & 3.5264 & 0.2691 & 1.0986 & 4.2905 \\
\hline MTB & 2,004 & 3.8185 & 2.7203 & 6.9092 & 0.4938 & 244.6308 \\
\hline SIZE & 2,004 & 22.7974 & 22.6194 & 1.3891 & 16.1613 & 28.5087 \\
\hline LEV & 2,004 & 0.5110 & 0.5139 & 24.8374 & -0.1947 & 7.0343 \\
\hline$R O A$ & 2,004 & 0.04 & 0.0373 & 17.3351 & -1.3470 & 7.1089 \\
\hline SALEG & 2,004 & 0.1392 & 0.0931 & 50.7778 & -0.7271 & 16.3427 \\
\hline CAPXR & 2,004 & 0.0735 & 0.0555 & 0.0699 & 0.0001 & 0.8368 \\
\hline OCFR & 2,004 & 0.0763 & 0.0616 & 0.6684 & 0 & 0.8570 \\
\hline ADVR & 2,004 & 0.0609 & 0.0369 & 7.3472 & 0.0001 & 0.5375 \\
\hline STATE & 2,004 & 0.9880 & 1 & 0.8335 & 0 & 2 \\
\hline
\end{tabular}




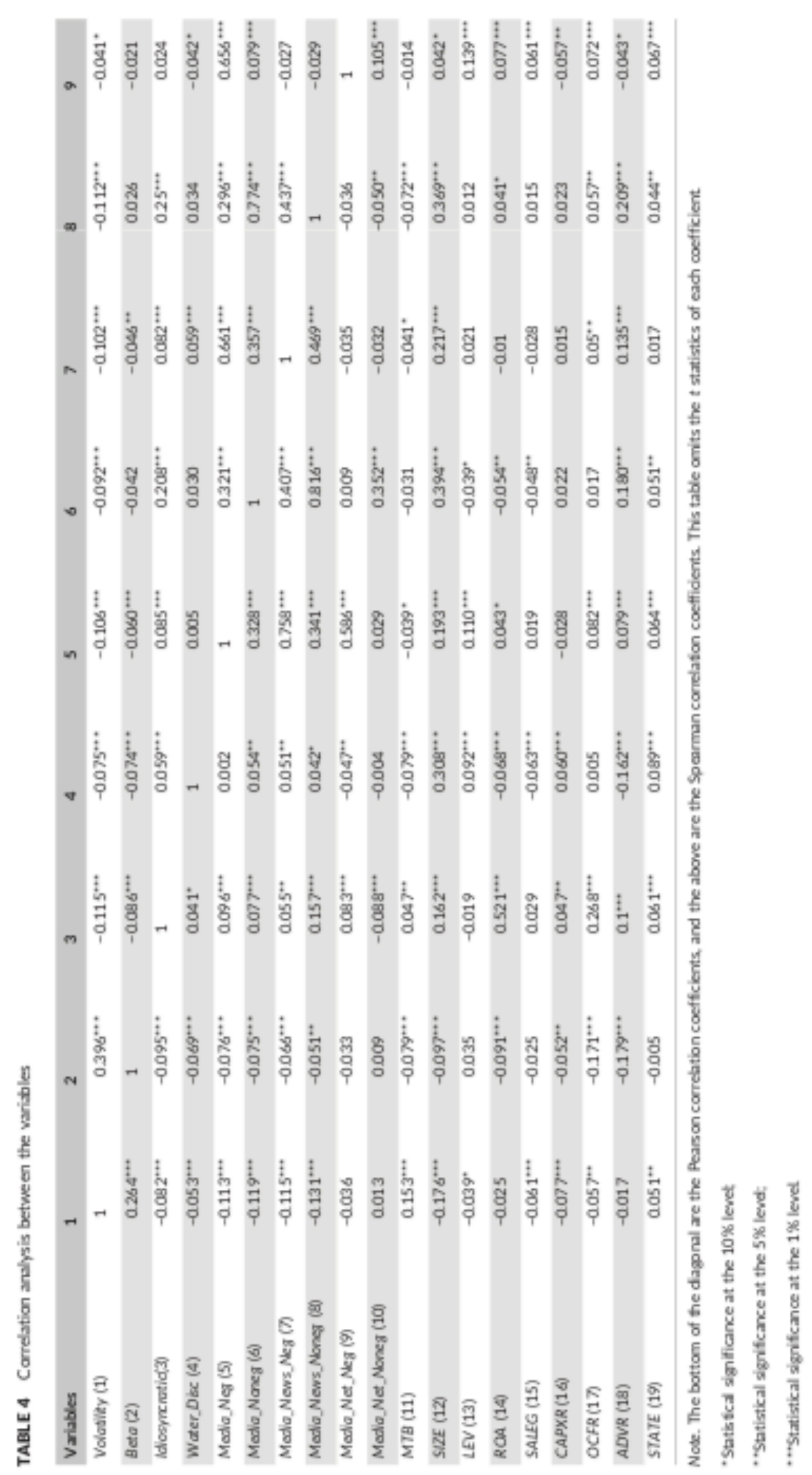




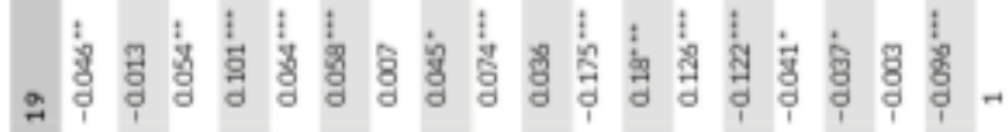

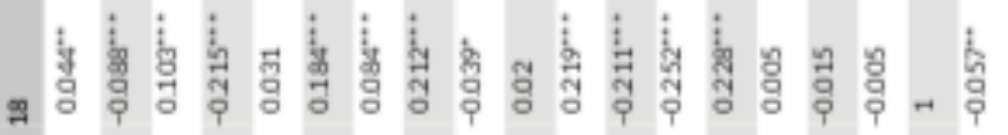

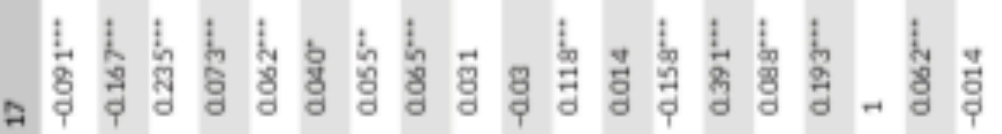

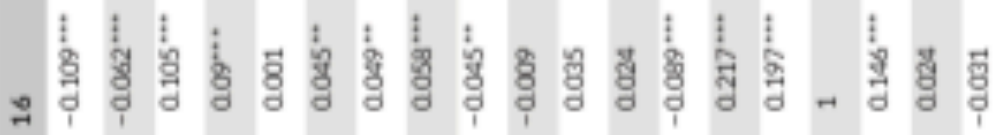

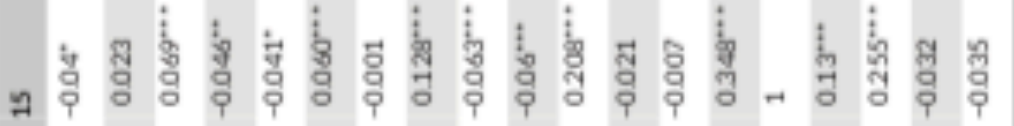

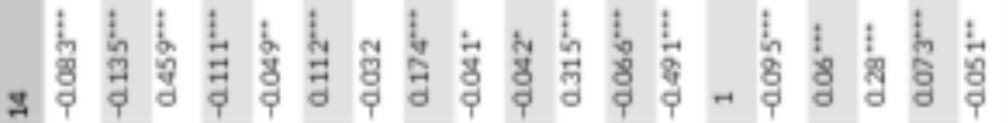

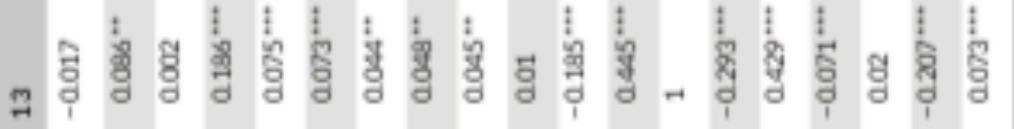

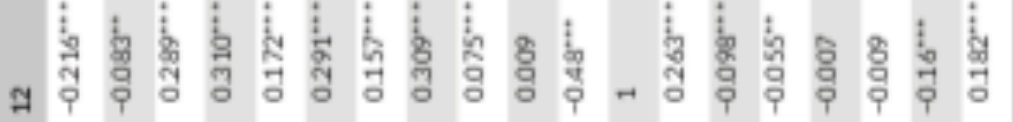

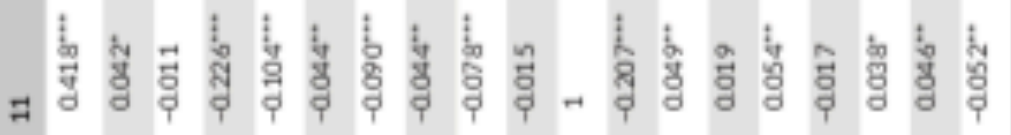

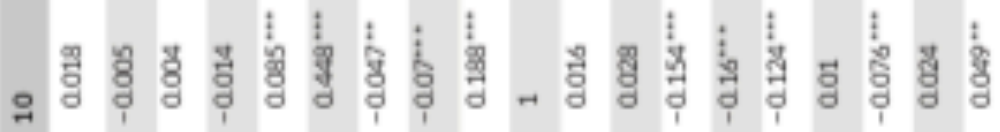

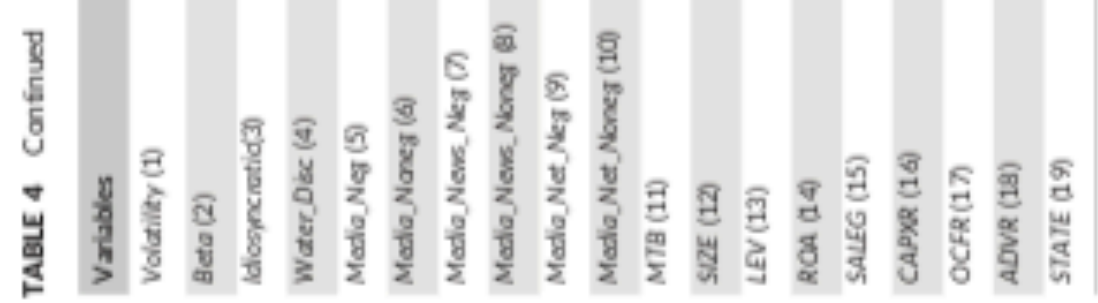




\section{Control variables}

With reference to previous research on environmental, social and water disclosure and firm risk (Benlemlih et al., 2016; Burritt et al., 2016; Cai et al., 2016; Jo \& Na, 2012; Oikonomou et al., 2012; Salama et al., 2011), we control for a series of a firm's characteristic variables, such as market-to-book ratio (MTB), firm size (SIZE), financial leverage $(L E V)$, return on assets $(R O A)$, sales growth $(S A L E G)$, capital expenditure expense scaled by total assets $(C A P X R)$, operating cash flows divided by total assets $(O C F R)$, advertising expense divided by total operating incomes $(A D V E R)$, and nature of enterprise (STATE). We also include industry and year dummy variables (fixed effects) into our regressions. The definition and measurement of all variables are presented in Table 2.

\section{Model specification}

We construct the following formula to analyze the relation between firm risk and water disclosure. We use contemporaneous values of firm risk, water disclosure, and control variables.

$$
\begin{aligned}
\text { Firm }^{-} \text {Risk }_{i, t}= & \beta_{0}+\beta_{1} \times \text { Water }^{-} \text {Disc }_{i, t}+\sum_{i} \beta_{i} \times \text { Controls }_{i, t} \\
& +\sum_{j} \beta_{j} \times \text { Industryfixedeffects }_{j}+\sum_{\mathrm{l}} \beta_{l} \times \text { Yearfixedeffect }_{\mathrm{I}} \\
& +\varepsilon_{\mathrm{it}}
\end{aligned}
$$

In order to further explore the moderating effect of media cover- age on the relationship between water disclosure and firm risk, we introduce the variables of nonnegative/negative media coverage and the interactive terms of nonnegative/negative media coverage and water disclosure into formula (3). Thus, we derive the following:

$$
\begin{aligned}
\text { Firm }^{-} \text {Risk }_{\mathrm{i}, \mathrm{t}} & =\beta_{0}+\beta_{1} \times \text { Water-Disc }_{\mathrm{i}, \mathrm{t}}+\beta_{2} \times \text { Media }_{\mathrm{i}, \mathrm{t}} \\
& +\beta_{3} \times \text { Media }_{\mathrm{i}, \mathrm{t}} \times \text { Water }^{-} \text {Disc }_{\mathrm{i}, \mathrm{t}}+\sum_{\mathrm{i}} \beta_{\mathrm{i}} \times \text { Controls }_{\mathrm{i}, \mathrm{t}} \\
& +\sum_{\mathrm{j}} \beta_{\mathrm{j}} \times \text { Industryfixedeffects }_{\mathrm{j}}+\sum_{\mathrm{l}} \beta_{\mathrm{l}} \times \text { Yearfixedeffect }_{\mathrm{l}} \\
& +\varepsilon_{\mathrm{it}} .
\end{aligned}
$$


In formulas (3) and (4), Firm $^{-}$Risk $k_{i, t}$ is one of the risk measures, and it comprises total risk, systematic risk, and idiosyncratic risk. Media $a_{i, t}$ represents media coverage (negative coverage and nonnegative media coverage). Controls $s_{i, t}$ represents the control variables in Table 2, where $i$ is the sample and $t$ is the year. Moreover, the Hausman-test result indicates that all regressions are suitable for use as fixed effect panel data models.

TABLE 5 Test results of the full sample (1)

\begin{tabular}{|c|c|c|c|c|c|c|}
\hline Variables & 1-1: Volatility & & 1-2: Beta & & 1-3: Idiosyncratic & \\
\hline Water_Disc & & $0.0003(1.47)$ & & $-0.0106 \cdots(-2.59)$ & & $0.0026(1.29)$ \\
\hline MTB & $0.0002^{\cdots *}(6.66)$ & $0.0024 \cdots(6.62)$ & $-0.0038 \cdots(-4.40)$ & $-0.0038 \cdots(-4.34)$ & $0.0011 \cdots(2.78)$ & $0.0011 \cdots(2.74)$ \\
\hline SIZE & $0.0045^{\cdots \cdots}(6.83)$ & $0.0432 \cdots(6.36)$ & $-0.0662 * \cdots(-4.27)$ & $-0.0575 \cdots(-3.63)$ & $0.0138^{*}(1.85)$ & $0.0117(1.53)$ \\
\hline LEV & $-0.0001^{*}(-1.75)$ & $-0.0001(-1.59)$ & $-0.0001(-0.26)$ & $-0.0002(-0.51)$ & $-0.0006 \cdots(-2.71)$ & $-0.0005^{* \cdots}(-2.56)$ \\
\hline$R O A$ & $0.00001(0.32)$ & $0.0006(0.39)$ & $-0.0003(-0.79)$ & $-0.0004(-0.91)$ & $0.00394 \cdots(19.92)$ & $0.0039 \cdots(19.96)$ \\
\hline SALEG & $-0.0004(-0.74)$ & $-0.0004(-0.73)$ & $0.0001(0.68)$ & $0.0001(0.67)$ & $0.0001(1.11)$ & $0.0001(1.11)$ \\
\hline CAPXR & $-0.0097^{* *}(-2.53)$ & $-0.0096 *(-2.49)$ & $0.0408(0.45)$ & $0.0354(0.39)$ & $0.1265 \cdots(2.92)$ & $0.1278 \cdots(2.64)$ \\
\hline OCFR & $0.0069^{*}(1.55)$ & $0.0068(1.50)$ & $-0.2345^{* *}(-2.22)$ & $-0.2263^{* *}(-2.15)$ & $0.1362 \cdots(2.68)$ & $0.1342 * *(2.64)$ \\
\hline ADVR & $0.0003 * *(2.50)$ & $0.0003 *(2.46)$ & $-0.0018(-0.66)$ & $-0.0016(-0.59)$ & $0.0016(1.26)$ & $0.0016(1.22)$ \\
\hline Constant & $-0.0762 * \cdots(-4.99)$ & $-0.0733^{* \cdots}(-4.76)$ & $2.6007^{* *}(7.29)$ & $2.4812 \cdots(6.90)$ & $-0.1803(-1.05)$ & $-0.1511(-0.87)$ \\
\hline YEAR & Yes & Yes & Yes & Yes & Yes & Yes \\
\hline IND & Yes & Yes & Yes & Yes & Yes & Yes \\
\hline Observations & 2,004 & 2,004 & 2,004 & 2,004 & 2,004 & 2,004 \\
\hline No. of firms & 334 & 334 & 334 & 334 & 334 & 334 \\
\hline$R^{2}(\%)$ & 27.94 & 28.95 & 31.01 & 32.80 & 30.02 & 29.96 \\
\hline
\end{tabular}

Note. Model 1-1, 1-2, and 1-3's dependent variables, respectively, are volatility, beta, and idiosyncratic, and their samples are all firms. $T$ statistics are shown in brackets.

-Statistical significance at the $10 \%$ level;

".Statistical significance at the $5 \%$ level;

-*Statistical significance at the $1 \%$ level. 


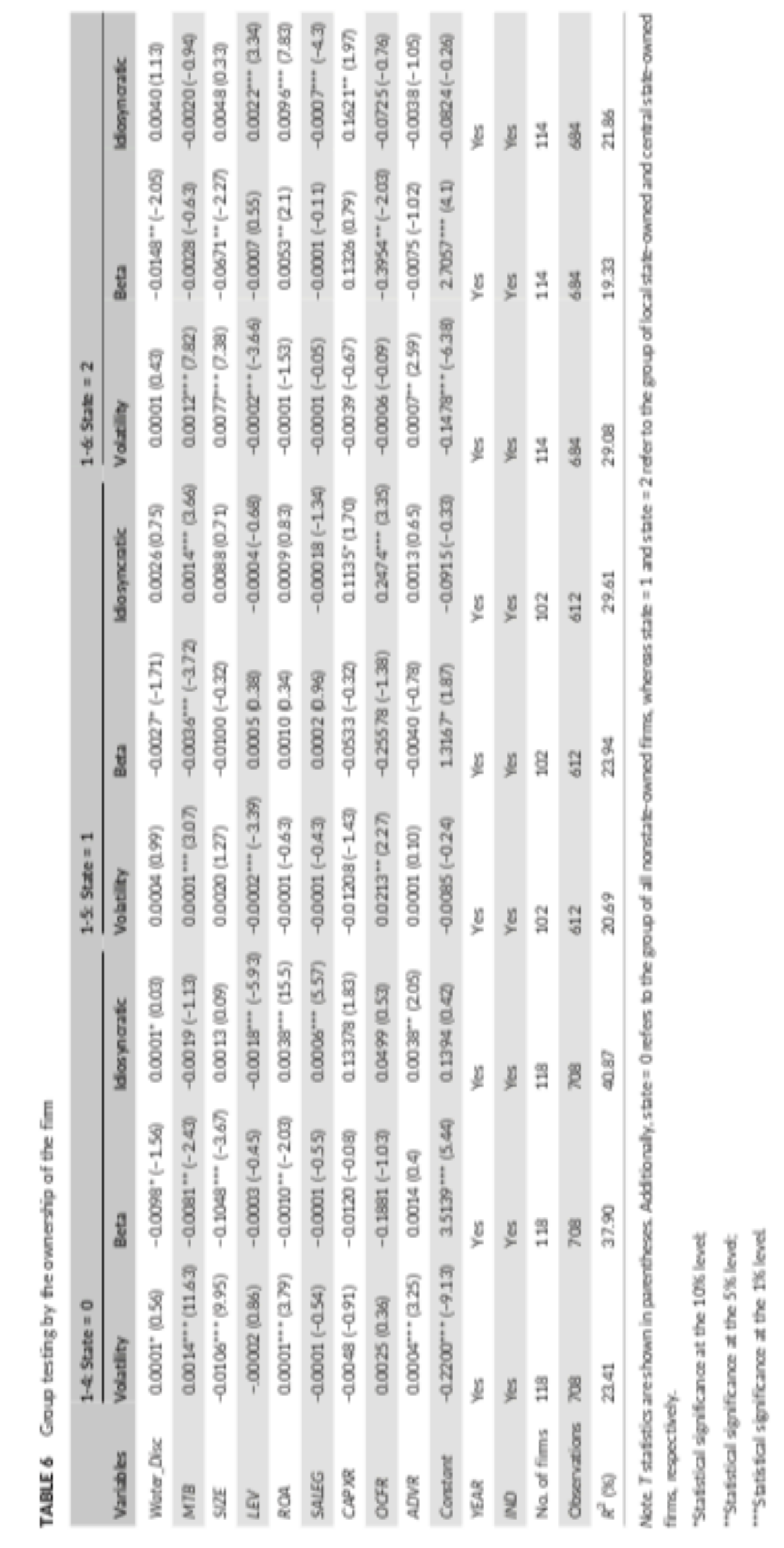




\section{EMPIRICAL RESULTS}

\section{Descriptive statistics and correlation analysis}

Table 3 provides the descriptive statistics of the variables in this paper. The results show that the average volatility of stock returns (total risk) is 0.0279 , and the total risk level of the samples is stable (the standard deviation is 0.0098). The mean of the systematic risk is 1.0445 , which indicates that the average systematic risk faced by the sample firms is higher than that of the whole stock market $(\beta=1.0445>1)$. The mean of idiosyncratic risk is 0.1592 , and the distribution is relatively scattered, which indicates that the environments of the sample firms' businesses are different. The risk indicators are consistent with those of prior studies, such as Oikonomou et al. (2012), Jo and $\mathrm{Na}$ (2012). From the average score of water disclosure (6.9586), it can be seen that the overall level of water disclosure of the sample firms is low, which suggests that water issues have not yet a major concern of these firms. From Table 3, it can be seen that both the Internet and newspapers prefer to report "nonnegative news" about the listed companies. The details of other control variables are shown in Table 3.

The Pearson correlation test (lower triangle) and Spearman correlation test (upper triangle) are used in this paper to identify whether there are any multicollinearity problems. Table 4 shows that idiosyncratic risk is significantly positively correlated with water disclosure, whereas total risk and systematic risk are significantly negatively correlated with water disclosure. Except for the variables regarding media coverage, the correlation coefficients of variables are less than 0.6 , indicating that our models are unlikely to suffer from multicollinearity problems.

\section{Hypothesis testing}

\section{Main effect testing}

Table 5 reports the test results of 1 in terms of total risk, systematic risk, and idiosyncratic risk. The results show that the regression coefficient for water disclosure and systematic risk is negative $(-0.0106)$ and are statistically significant at the level of $1 \%$ (Model 1-2). However, the relationships between water disclosure and idiosyncratic risk (Model 1-3) and total 
risk (Model 1-1) are not statistically significant.

TABLE 7 Moderating effects of media coverage-Overall (2a and 2b)

\begin{tabular}{|c|c|c|c|c|c|c|}
\hline \multirow[b]{3}{*}{ Variables } & \multicolumn{6}{|c|}{ The moderating effect test of the media coverage (Newspaper + Internet) } \\
\hline & \multicolumn{2}{|l|}{ Volatility } & \multicolumn{2}{|l|}{ Beta } & \multicolumn{2}{|l|}{ Idiosyncratic } \\
\hline & $2-1(2 a)$ & $2-2(2 b)$ & $2-3(2 a)$ & $2-4(2 b)$ & $2-5(2 a)$ & $2-6(2 b)$ \\
\hline Water_Disc & $0.0010^{*}(1.65)$ & $0.0005(0.42)$ & $-0.0051^{* *}(-1.97)$ & $-0.0214^{*}(-1.83)$ & $-0.0044^{*}(-1.73)$ & $0.0535^{*}(1.91)$ \\
\hline Media_Neg & $0.0025(1.56)$ & & $0.0297(0.79)$ & & $-0.0212(-1.20)$ & \\
\hline Water_Disc"Midea_Neg & $-0.0005^{* *}(-2.27)$ & & $-0.0035^{* *}(-2.06)$ & & $0.0047^{*}(1.90)$ & \\
\hline Media_Noneg & & $0.0012(0.56)$ & & $0.0475(0.96)$ & & $0.1171^{\cdots *}(4.92)$ \\
\hline Water_Dis"Media_Noneg & & $-0.0001(-0.18)$ & & $0.0028^{* *}(0.43)$ & & $-0.0130^{* * *}(-4.15)$ \\
\hline MTB & $0.0002^{* * *}(6.60)$ & $0.0002^{* * *}(6.57)$ & $-00038^{* *}(-4.32)$ & $-0.0039^{* * *}(-4.43)$ & $0.0012^{* * *}(2.78)$ & $0.0010^{* *}(2.49)$ \\
\hline SIZE & $0.0043^{* * *}(6.39)$ & $0.0043^{* * *}(6.30)$ & $-0.0572^{* * *}(-3.60)$ & $-0.0559^{\cdots *}(-3.51)$ & $0.0116(1.52)$ & $0.0082(1.07)$ \\
\hline LEV & $-0.0001^{*}(-1.73)$ & $-0.0001^{*}(-1.42)$ & $-0.0003(-0.62)$ & $-0.0002(-0.43)$ & $-0.0006 *(-2.44)$ & $-0.0003(-1.14)$ \\
\hline$R O A$ & $0.0001(0.19)$ & $0.0001(0.50)$ & $-0.0004(-0.99)$ & $-0.0003(-0.73)$ & $0.0040^{* \cdots}(20.03)$ & $0.0042^{* \cdots *}(20.67)$ \\
\hline SALEG & $-0.0001(-0.78)$ & $-0.0001(-0.78)$ & $0.00001(0.71)$ & $0.0001(0.58)$ & $0.0001(0.17)$ & $0.0001(0.62)$ \\
\hline CAPXR & $-0.0096^{* *}(-2.50)$ & $-0.0099^{* *}(-2.56)$ & $0.0378(0.42)$ & $0.0097(0.11)$ & $0.1284^{* *}(2.96)$ & $0.1184^{\cdots *}(2.74)$ \\
\hline OCFR & $0.0068(1.50)$ & $0.0069(1.53)$ & $-0.2245^{* *}(-2.13)$ & $-0.2233^{* *}(-2.03)$ & $0.1346^{\cdots *}(2.65)$ & $0.1371^{* *}(2.71)$ \\
\hline ADVR & $0.0003^{* *}(2.56)$ & $0.0003^{* *}(2.48)$ & $-0.0017(-0.61)$ & $-0.0014(-0.52)$ & $0.0015(1.13)$ & $0.0017(1.30)$ \\
\hline Constant & $-0.0772^{* * *}(-4.95)$ & $-0.0779^{* * *}(-4.60)$ & 2. $4298^{* *}(6.65)$ & $2.2604^{* *}(5.73)$ & $-0.1172(-0.67)$ & $-0.5418^{* \cdots}(-2.86)$ \\
\hline YEAR & Yes & Yes & Yes & Yes & Yes & Yes \\
\hline IND & Yes & Yes & Yes & Yes & Yes & Yes \\
\hline No. of firms & 334 & 334 & 334 & 334 & 334 & 334 \\
\hline Observations & 2,004 & 2,004 & 2,004 & 2,004 & 2,004 & 2,004 \\
\hline$R^{2}(\%)$ & 28.30 & 29.06 & 31.80 & 38.30 & 30.45 & 30.44 \\
\hline
\end{tabular}

Note. $T$ statistics are shown in parentheses.

"Statistical significance at the $10 \%$ level;

*'Statistical significance at the $5 \%$ level;

**Statistical significance at the $1 \%$ level.

The results are partially consistent with the findings of Jo and $\mathrm{Na}$ (2012) but very different from the findings of Benlemlih et al. (2016). The above test results differ significantly from our expectation; thus, 1 is partially supported.

In addition, in order to analyze the impact of water disclosure on firm risk against the background of equity property differences, we group the sample firms according to each firm's actual ownership (private firms, central state-owned firms, and local state-owned firms) and further tested our hypotheses, as shown in Table 6. In general, the ownership of a firm does not lead to a difference in how water disclo- sure affects firm risk. No matter a firm is state-owned (central/local state-owned) or private, systematic risk has a reverse relationship with the degree of water disclosure.

Compared with state-owned firms, water disclosure's impact on private firms is more significant (both are significant at the $10 \%$ level). 


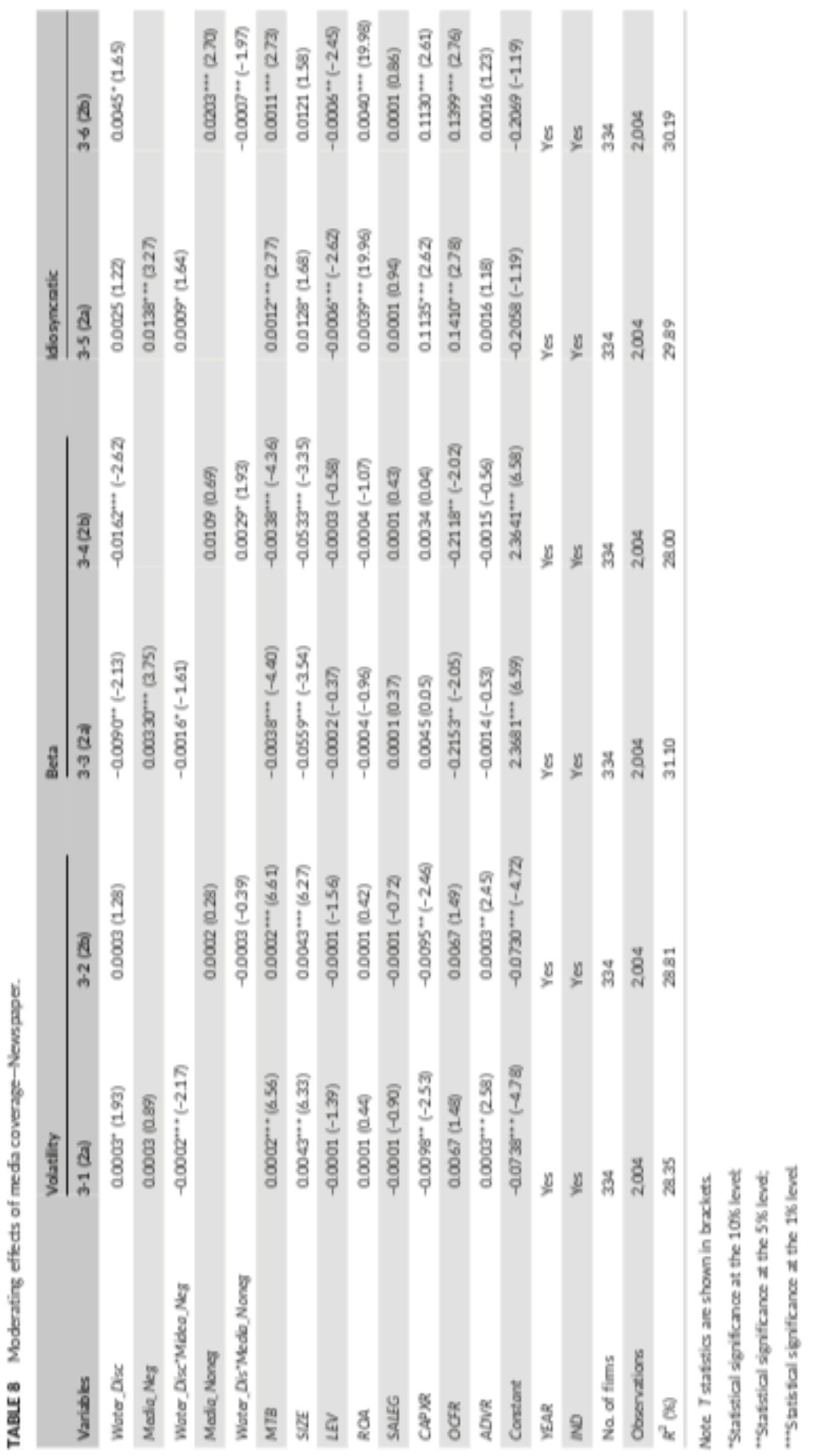




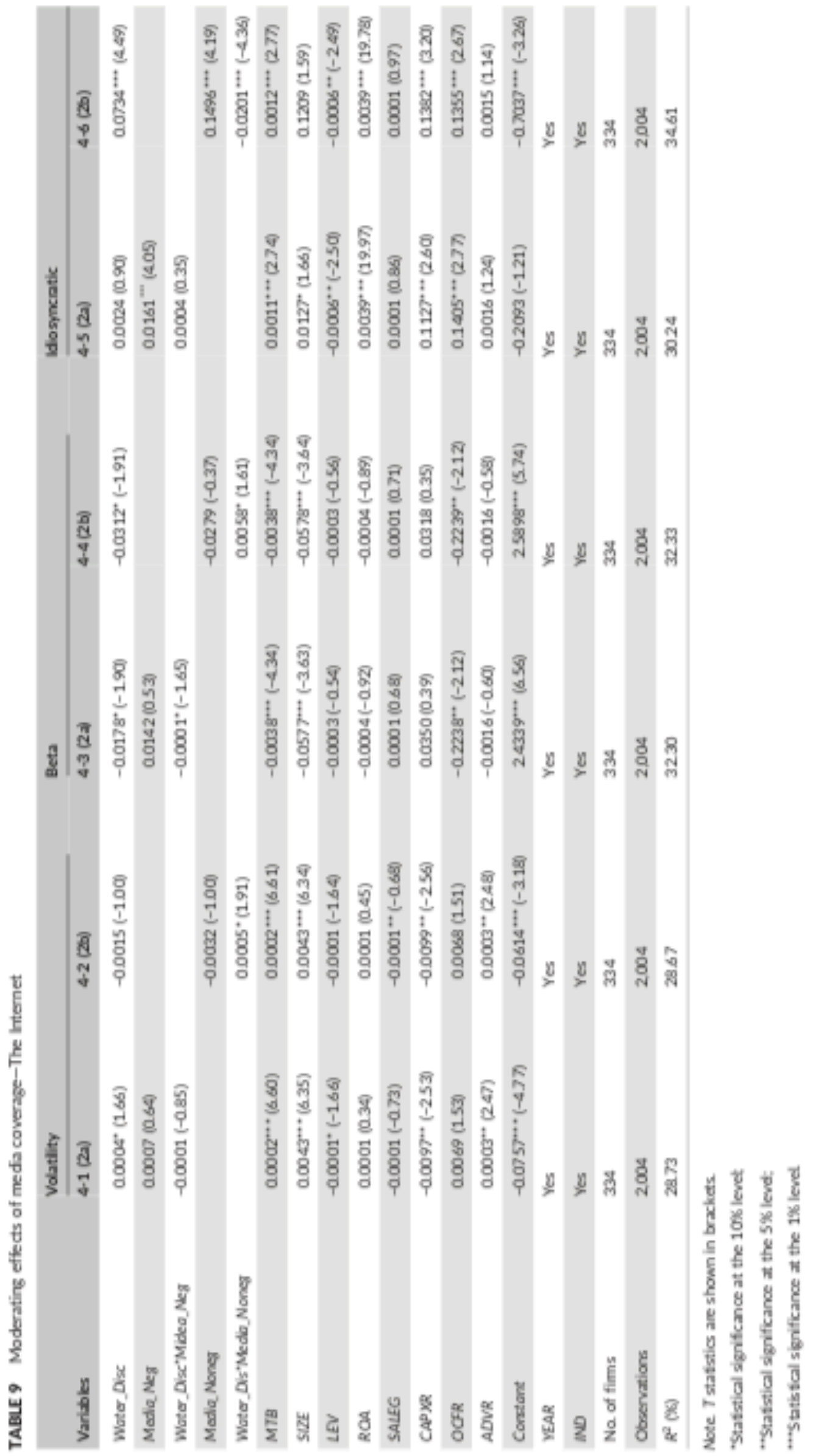




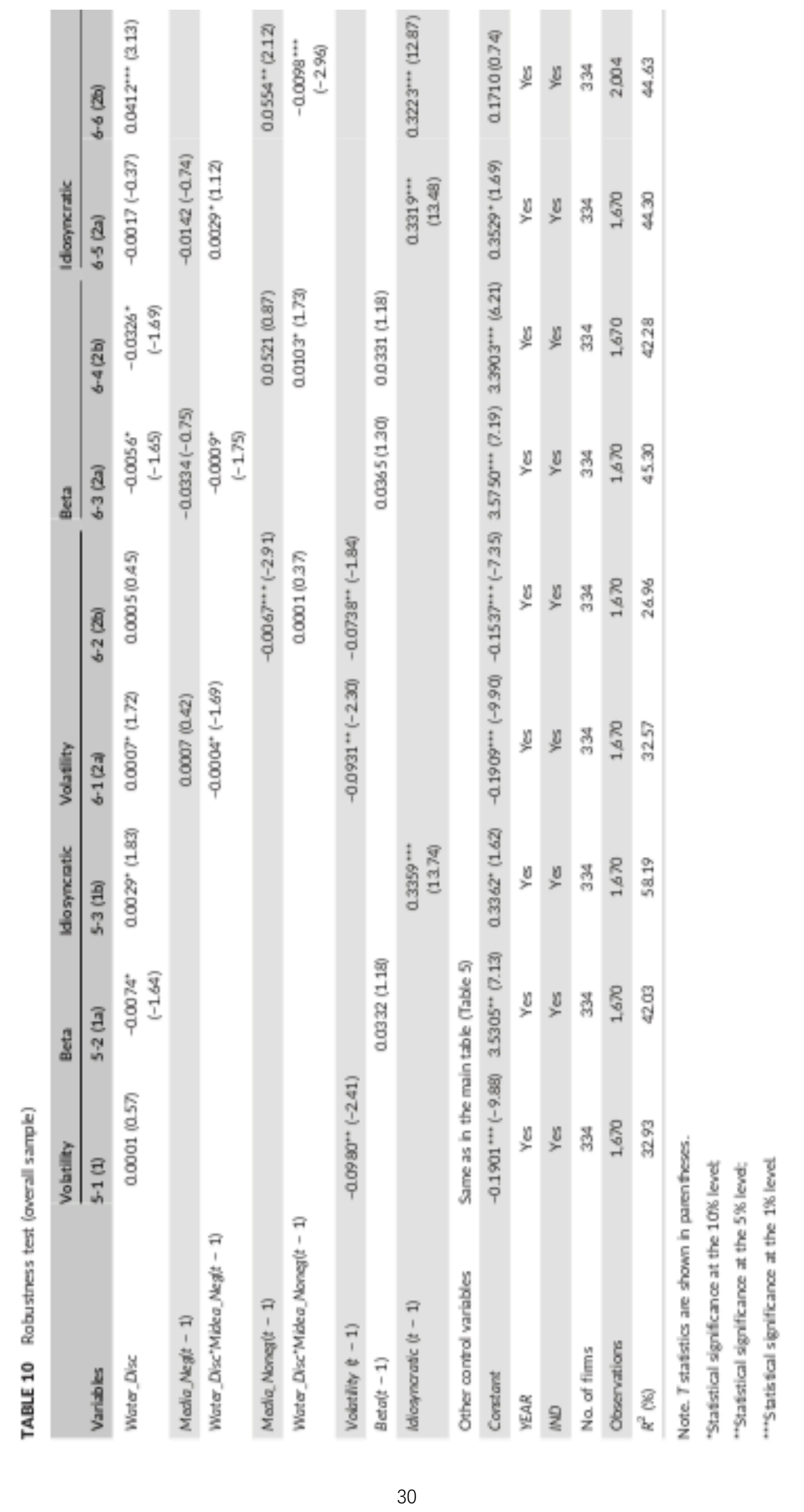




\section{Moderating effect testing}

In Table 7, we can see that negative media coverage weakens the negative WD-TR (Model 2-1) and WD-SR (Model 2-3) relationships, which supports 2a, but it enhances the negative WD-IR relationship, which is contrary to 2a. Considering the fact that in our main effect test, the WD-TR and WD-IR relationships are not statistically significant, we believe that $2 \mathrm{a}$ is only partially supported, that is, negative media coverage can negatively moderate the WD-SR relationship. On the other hand, although nonnegative media coverage does not now show a significant moderating effect on the WD-TR relationship (Model 2-2), it exhibits a positive moderating effect on the WD-SR relationship (Model 2-4) and a negative moderating effect on the WDIR relationship (Model 2-6). Again, due to the fact that in our mail effect test, the WD-TR and WD-IR relationships are not statistically significant, we believe that nonnegative media coverage positively moderates the WD-SR relationship, which means $2 b$ is partially sup- ported. In order to further investigate negative and nonnegative media coverages' moderating effects on the relationship between water dis- closure and firm risk, we distinguish media coverage by newspaper (Table 8) and the Internet (Table 9). From Tables 8 and 9, we can see that both the negative moderating effect of negative media coverage (Models 3-3 and 4-3) and the positive moderating effect of nonnegative media coverage (Models 3-4 and 4-4) on the WDSR relationship hold, whereas in other cases they vary. Therefore, the overall moderating testing shows that both $2 \mathrm{a}$ and $2 \mathrm{~b}$ are partially supported, that is, negative media coverage negatively moderates the WD-SR relation- ship, and nonnegative media coverage positively moderates the WD-SR relationship.

\section{Potential endogenous controlling}

Prior studies (Cai et al., 2016; Jo \& Na, 2012) argue that a firm's risk and corporate environmental and social disclosures could be endogenous; this has been posited in order to rule out potentially omitted control variables. In the light of this, we take a series of measures to control any possible endogeneity issues to improve the robustness of our findings. 
TABLE 11 Robustness test of $2 \mathrm{a}$ and $2 \mathrm{~b}$ (newspaper subsample)

\begin{tabular}{|c|c|c|c|c|c|c|}
\hline \multirow[b]{2}{*}{ Variables } & \multicolumn{2}{|l|}{ Volatility } & \multicolumn{2}{|l|}{ Beta } & \multicolumn{2}{|l|}{ Idiosyncratic } \\
\hline & $7-1(2 a)$ & $7-2(2 b)$ & $7-3(2 a)$ & $7-4(2 b)$ & $7-5(2 a)$ & $7-6(2 b)$ \\
\hline Water_Disc & $0.0004^{*}(1.76)$ & $0.0007^{* *}(2.20)$ & $-00041^{*}(-1.67)$ & $-0.0058^{*}(-1.70)$ & $0.0014(0.54)$ & $0.0032(0.90)$ \\
\hline Media_Neg(t-1) & $0.0007(0.51)$ & & $0.0122(0.36)$ & & $-0.0154(-1.05)$ & \\
\hline Water_Disc"Midea_Neg(t - 1) & $-0.0003^{*}(-1.94)$ & & $-0.0040^{*}(-1.87)$ & & $0.0021(1.07)$ & \\
\hline Media_Noneg(t - 1) & & $-0.0018^{* *}(-2.02)$ & & $0.0670^{* * *}(2.91)$ & & $0.0076(0.77)$ \\
\hline Water_Disc"Midea__Noneg(t - 1) & & $-0.0002^{* *}(-2.18)$ & & $0.0060 * *(2.00)$ & & $-0.0002(-0.13)$ \\
\hline Volatility $(t-1)$ & $-0.0899^{* * *}(-2.22)$ & $-0.0387(-0.97)$ & & & & \\
\hline Beta $(t-1)$ & & & $0.0331(1.17)$ & $0.0211(0.75)$ & & \\
\hline Idiosyncratic (t - 1) & & & & & $0.3365^{* * *}(13.75)$ & $0.3308 * * *(13.41)$ \\
\hline Other control variables & Same as in the main & table (Table 5) & & & & \\
\hline Constant & $-0.1885^{* * *}(-9.87)$ & $-0.1759^{* * *}(-9.39)$ & $3.5521^{* * *}(7.17)$ & $3.4118^{* * *}(6.88)$ & $0.3358^{*}(1.62)$ & $0.2982(1.43)$ \\
\hline YEAR & Yes & Yes & Yes & Yes & Yes & Yes \\
\hline IND & Yes & Yes & Yes & Yes & Yes & Yes \\
\hline No. of firms & 334 & 334 & 334 & 334 & 334 & 334 \\
\hline Observations & 1,670 & 1,670 & 1,670 & 1,670 & 1,670 & 1,670 \\
\hline$R^{2}(\%)$ & 32.22 & 22.67 & 41.80 & 38.20 & 44.25 & 44.23 \\
\hline
\end{tabular}

Note. $T$ statistics are shown in parentheses.

"Statistical significance at the $10 \%$ level;

*"Statistical significance at the $5 \%$ level;

**Statistical significance at the $1 \%$ level.

TABLE 12 Dynamic system generalized method of moment regression

\begin{tabular}{|c|c|c|c|}
\hline Variables & 8-1: Volatility & 8-2: Beta & 8-3: Idiosyncratic \\
\hline Volatility $(t-1)$ & $-0.9004^{* * *}(-9.06)$ & & \\
\hline Volatility $(t-2)$ & $-0.2056 * *(-5.28)$ & & \\
\hline Beta $(t-1)$ & & $-0.0207^{*}(-1.70)$ & \\
\hline Beta $(t-2)$ & & $-0.5935^{* * *}(-17.53)$ & \\
\hline Idiosyncratic(t - 2) & & & $-0.2942^{* * *}(-13.56)$ \\
\hline Other control variables & \multicolumn{3}{|c|}{ Same as in the main table (Table 5) } \\
\hline Constant & $-0.1819^{* * *}(-6.98)$ & & $0.3261(1.02)$ \\
\hline YEAR & Yes & Yes & Yes \\
\hline
\end{tabular}

Note. Z statistics are shown in parentheses.

"Statistical significance at the $10 \%$ level;

" Statistical significance at the $5 \%$ level;

**Statistical significance at the $1 \%$ level. 
We rule out the deviation of results caused by potentially omitted variables by adding control variables. Based on Jo and $\mathrm{Na}$ (2012), we carry out a new regression analysis by introducing the lag of firm risk as a control variable into the model. Additionally, based on Dai, Pan, and Chen (2013), we use the moderating effect test method to lag media coverage. Tables 10 and 11 (with newspaper subsample as an example) show that our robustness testing results are consistent with the previous results. We also use the generalized method of moment system dynamic model to mitigate the impact of missing variables on the negative correlation between water disclosure and firm risk. The generalized method of moment system dynamic model is mainly used to solve endogenous problems caused by reverse correlation and missing variables, and it is usually used as a robustness test. In this paper, we examine the relationship between water disclosure and firm risk by drawing on the treatment of Blundell and Bond (1998); Wintoki, Linck, and Netter (2012); and Cai et al. (2016). The results in Table 12 show the significant negative WD-SR relationship holds, which demonstrates the robustness of our main findings.

\section{DISCUSSION AND CONCLUSIONS}

Water issues are widely recognized as an important source of firm risk in the context of increased resource constraints and tightening environmental regulations (Burritt et al., 2016; Kurland \& Zell, 2010; Reig, Shiao, \& Gassert, 2013). Our study uses a sample of 334 Chinese listed firms operating in highly water-sensitive industries to empirically explore the relationship between water disclosure and firm risk. To the best of our knowledge, our study is the first one investigating the relationship between water disclosure and firm risk in business ethics literature. Although we have not found any significant relationship between water disclosure and firms' total risk and idiosyncratic risk, we have found a significant relationship between water disclosure and systematic risk; we have also found that negative/nonnegative media coverage can negatively/positively moderate this negative WD-SR relationship. Interestingly, our empirical findings are very different from Benlemlih et al. (2016), which used a composite overall environmental disclosure indicator and found that, whereas there is 
no significant relationship between environmental disclosure and systematic risk, there are significant relationships between environmental disclosure and firms' total risk and idiosyncratic risk. Our findings are somewhat in line with Salama et al. (2011), Oikonomou et al. (2012), Jo and Na (2012), and Cai et al. (2016; all these studies focused on the impact of overall CSR disclosure on firm risk). The underlying mechanism behind our expected empirical findings deserves in-depth discussions. We explain these differences from the following perspectives. First, the measures used in previous studies, for example, CSR disclosures in Jo and $\mathrm{Na}$ (2012) and Gregory, Whittaker, and Yan (2016) and environmental and social disclosures in Benlemlih et al. (2016), Cai et al. (2016), and de Villiers and Marques (2016), are composite indicators which cover multiple dimensions. Environmental information is just one dimension of these composite indicators, and water information is a part of the environmental dimension. Using composite indicators can reveal the effect of overall CSR disclosure on firm risk. It, however, cannot reveal how a specific type of environmental disclosure (in our case water disclosure) can affect firm risk. In our case, the differences between our empirical findings and those in previous studies are caused by the nature of water disclosure in China. Although the Ministry of Ecology and Environment of China issued the Measures for the Disclosure of Environmental Information on May 1, 2008, practically the government does not require listed companies to disclose water information. Water disclosure is still a voluntary immature environmental activity in the Chinese capital market. Only $38 \%$ of Chinese listed firms currently disclose their total water consumption (CDP, 2016). The descriptive statistics in Table 3 shows currently in China listed firms' water disclosure level is still low (with mean $=6.9586, \min =2$, and $\max =15$ ). With a low level of water dis- closure, both firms and their external stakeholders lack the awareness of water issues. External stakeholders (especially shareholders) would not view issues related to water management and utilization as a firm's internal risks. Therefore, in our study, water disclosure does not have a significant effect on idiosyncratic risk (and total risk).

Second, these differences are caused by the macrolevel institutional/regulatory 
setting in China. China's fastest economic growth in the world entails a lot of severe environmental problems, for example, smog cities, resource depletion, soil contamination, and water pollution. In order to tackle these environmental challenges, the Chinese government has launched a series of environmental regulations. However, although the Chinese government shows a strong will to improve the country's environment, how these macrolevel environmental regulations can be effectively implemented at firm-level is still a question awaiting solutions. Currently, in China, there are no stable macrolevel mechanisms to balance the economic development and environmental protection. The environmental institutional/regulatory framework in China always varies, which has caused market uncertainties. External stakeholders weigh these environment-related market uncertainties, which means that listed firms face systematic risk. Disclosing more water information as a means to comply with the government's desire for environmental protection can help listed firms in highly water-sensitive industries gain government support, which in turn reduces their systematic risk. Therefore, in China's particular macrolevel institutional/regulatory setting, water disclosure is negatively related to firms' systematic risk.

Our empirical findings have also confirmed the role of the media as an external mechanism for corporate governance (Pollach, 2014; Tian, Feng, \& Yu, 2016). As we expected, negative/nonnegative media coverage can weaken/enhance the negative relationship between water disclosure and systematic risk. Therefore, the media can act as an external means to exert supervisory power on firms' environmental practice. We have explained this mechanism using the agenda-setting theory. We believe that at the moment the media plays a particularly important role in terms of pushing corporate water disclosure forward in China. As currently water disclosure is an immature environmental practice, arousing firms' awareness of water issues is particularly important. The media can make topics on water issues salient in the society. When firms are highly aware of water issues and they know nonnegative media coverage can help them to reduce risk, they would actively contribute to water resource management and disclose their water information.

Our research can offer some managerial implications for Chinese listed firms to 
handle firm risk. At the current stage, although corporate water disclosure in China is immature, our empirical findings have confirmed that it can reduce systematic risk. Therefore, managers should pay more attention to water disclosure and can use it as an effective means to reduce firm risk. We foresee that in the near future the Chinese government will introduce more environmental regulations to protect water resource, which will make the macrolevel environmental institutional/regulatory framework stable and reduce the market uncertainty. When the institutional/regulatory framework is stable and mature, external stakeholders would be highly aware of water problems and view corporate water management and utilization as a firm's internal risk. We speculate that, at that stage, water disclosure will be negatively related to firms' idiosyncratic risk. Therefore, managers should make continuous effort to promote water disclosure. Additionally, as nonnegative media coverage can reinforce the negative relationship between water disclosure and systematic risk, man- agers should properly use the media. Disseminating positive messages about their corporate water management and utilization to the media would reinforce their effort on risk reduction.

Nonetheless, we need to acknowledge the limitations of our study that may be addressed in future research. First, due to the fact that water disclosure is still an immature business practice in China, the findings from our empirical setting may not be applicable to other empirical setting. Future research can empirically examine the relationship between water disclosure and firm risk using other empirical settings, for example, it would be very interesting to conduct such a study using empirical data from a developed market where the environmental institutional/regulatory framework is mature and stable.

Second, compared with research about carbon disclosure, research about water disclosure is still in its infancy. Therefore, quantitative measures of the water disclosure are still in the exploratory stage. Likewise, the selecting, setting, and measuring methods of the key water disclosure indexes require improvement. Further research is required to develop more general water disclosure measures. 


\section{REFERENCES}

Aerts, W., Cormier, D., \& Magnan, M. (2006). Intra-industry imitation in corporate environmental reporting: An international perspective. Journal of Accounting and Public Policy, 25(3), 299-331. https://doi.org/ 10.1016/j.jaccpubpol.2006.03.004 Alrazi, B., de Villiers, C., \& Van Staden, C. J. (2016). The environmental dis- closures of the electricity generation industry: A global perspective. Accounting and Business Research, 46, 665-701. https://doi.org/ 10.1080/00014788.2015.1135781

Al-Tuwaijri, S. A., Christensen, T. E., \& Hughes, K. E. II (2004). The relations among environmental disclosure, environmental performance, and economic performance: A simultaneous equations approach. Accounting, Organizations and Society, 29(5), 447471. https://doi.org/10.1016/ S0361-3682(03)00032-1

Bansal, P., \& Clelland, I. (2004). Talking trash: Legitimacy, impression management, and unsystematic risk in the context of the natural environment. Academy of Management Journal, 47(1), 93-103.

Barber, M., \& Jackson, S. (2012). Indigenous engagement in Australian mine water management: The alignment of corporate strategies with national water reform objectives. Resources Policy, 37(1), 48-58.

https://doi.org/10.1016/j.resourpol.2011.12.006

Ben-Amar, W., \& Chelli, M. (2018). What drives voluntary corporate water disclosures? The effect of country-level institutions. Business Strategy and the Environment, 27, 1609-1622. https://doi.org/10.1002/ bse.2227

Benlemlih, M., Shaukat, A., Qiu, Y., \& Trojanowski, G. (2016). Environmental and social disclosures and firm risk. Journal of Business Ethics, 152, 613-626.

https://doi.org/10.1007/s10551-016-3285-5

Beyer, A., \& Guttman, I. (2012). Voluntary disclosure, manipulation, and real effects. Journal of Accounting Research, 50(5), 1141-1177. https://doi.org/10.1111/j.1475679X.2012.00459.x

Birkey, R. N., Michelon, G., Patten, D. M., \& Sankara, J. (2016). Does assurance on CSR reporting enhance environmental reputation? An examination in the U.S. context. Accounting Forum, 40(3), 143-152. 
https://doi.org/10.1016/j.accfor.2016.07.001

Blundell, R., \& Bond, S. (1998). Initial conditions and moment restrictions in dynamic panel data models. Journal of Econometrics, 87(1), 115-143.

https://doi.org/10.1016/S0304-4076(98)00009-8

Botha, M. J., \& Middelberg, S. L. (2016). Evaluating the adequacy of water- related reporting and disclosure by high-impact users in South Africa. Journal of Environmental Assessment Policy and Management, 18(01), 1650003-1650020). https://doi.org/10.1142/S1464333216500034 Brown, N., \& Deegan, C. (1998). The public disclosure of environmental performance information: A dual test of media agenda setting theory and legitimacy theory. Accounting and Business Research, 29(1), 21-41. https://doi.org/10.1080/00014788.1998.9729564 Burritt, R. L., \& Christ, K. L. (2018). Water risk in mining: Analysis of the Samarco dam failure. Journal of Cleaner Production, 178, 196-205.

https://doi.org/10.1016/j.jclepro.2018.01.042

Burritt, R. L., Christ, K. L., \& Omori, A. (2016). Drivers of corporate water- related disclosure: Evidence from Japan. Journal of Cleaner Production, 129, 65-74. https://doi.org/10.1016/j.jclepro.2016.04.119

Bushee, B. J., Core, J. E., Guay, W., \& Hamm, S. J. W. (2010). The role of the business press as an information intermediary. Journal of Accounting Research, 48(1), 1-19. https://doi.org/10.1111/j.1475- 679X.2009.00357.X

Cahan, S. F., Chen, C., Chen, L., \& Nguyen, N. H. (2015). Corporate social responsibility and media coverage. Journal of Banking \& Finance, 59, 409-422. https://doi.org/10.1016/j.jbankfin.2015.07.004 Cai, L., Cui, J., \& Jo, H. (2016). Corporate environmental responsibility and firm risk. Journal of Business Ethics, 139(3), 563-594. https://doi.org/ 10.1007/s10551-015$2630-4$

CDP. (2010). CDP water disclosure 2010: Global report. London: Carbon disclosure project.

CDP. (2015). Accelerating action: CDP global water report 2015. London: Carbon 
disclosure project.

CDP. (2016). CDP China water report 2016. London: Carbon disclosure project. CEO Water Mandate (2008). The CEO water mandate transparency frame- work (phase one). Oakland, California USA: The Pacific Institute.

CEO Water Mandate (2014). Corporate water disclosure guidelines: Toward a common approach to reporting water issues. Oakland, CA: CEO Water Mandate. Certo, S. T., \& Hodge, F. (2007). Top management team prestige and organizational legitimacy: An examination of investor perceptions. Journal of Managerial Issues, $19(4), 461-477$.

Cheung, A. (2016). Corporate social responsibility and corporate cash holdings. Journal of Corporate Finance, 37, 412-437. https://doi.org/ 10.1016/j.jcorpfin.2016.01.008

Cho, C., \& Patten, D. (2007). The role of environmental disclosures as tools of legitimacy: A research note. Accounting, Organizations and Society, 32, 639-647. https://doi.org/10.1016/j.aos.2006.09.009

Clarkson, P. M., Li, Y., Richardson, G. D., \& Vasvari, F. P. (2008). Revisiting the relation between environmental performance and environmental disclosure: An empirical analysis. Accounting, Organizations and Society, 33, 303-327.

https://doi.org/10.1016/j.aos.2007.05.003

Dai, Y., Pan, Y., \& Chen, F. (2013). Media coverage, government governance and auditor switch. Accounting Research, 33(10), 89-95.

Dawkins, C., \& Fraas, J. W. (2011). Coming clean: The impact of environ- mental performance and visibility on corporate climate change disclosure. Journal of Business Ethics, 100(2), 303-322. https://doi. org/10.1007/s10551-010-0681-0 de Villiers, C., \& Marques, A. (2016). Corporate social responsibility, country-level predispositions, and the consequences of choosing a level of disclosure. Accounting and Business Research, 46(2), 167-195.

https://doi.org/10.1080/00014788.2015.1039476

Delgado-García, J. B., de Quevedo-Puente, E., \& Díez-Esteban, J. M. (2013). The impact of corporate reputation on firm risk: A panel data analysis of Spanish quoted 
firms. British Journal of Management, 24(1), 1-20. https://doi.org/10.1111/j.14678551.2011.00782.x

Dennis, P., Connole, H., \& Kraut, M. (2015). The efficacy of voluntary dis- closure: A study of water disclosure by mining companies using the global reporting initiative framework. Journal of Legal, Ethical and Regulatory Issues, 18(2), 87-106.

DiMaggio, P. J., \& Powell, W. W. (1983). The iron cage revisited: Institutional isomorphism and collective rationality in organizational fields. American Sociological Review, 48(2), 147-160. https://doi.org/ 10.2307/2095101

Duan, Y., Hu, G., \& McLean, D. (2010). Costly arbitrage and idiosyncratic risk: Evidence from short-sellers. Journal of Financial Intermediation, 19(4), 564-579. https://doi.org/10.1016/j.jfi.2009.06.003 Egan, M. (2014). Making water count: Water accountability change within an Australian university. Accounting, Auditing \& Accountability Journal, 27(2), 259282. https://doi.org/10.1108/AAAJ-07-2012-01059

Fang, L., \& Peress, J. (2009). Media coverage and the cross-section of stock returns. Journal of Finance, 64(5), 2023-2052. https://doi.org/ 10.1111/j.15406261.2009.01493.x

Fombrun, C. (1998). Indices of corporate reputation: An analysis of media rankings and social monitors' ratings. Corporate Reputation Review, 1(4), 327-340. https://doi.org/10.1057/palgrave.crr.1540055 Fombrun, C., \& Shanley, M. (1990). What's in a name? Reputation building and corporate strategy. Academy of Management Journal, 33(2), 233-258. Fombrun, C. J., \& Rindova, V. (1996). Who's tops and who decides? The social construction of corporate reputations. New York City, NY: New York University, Stern School of Business.

Gallego-Alvarez, I., Ortas, E., Vicente-Villardón, J. L., \& Álvarez Etxeberria, I. (2017). Institutional constraints, stakeholder pressure and corporate environmental reporting policies. Business Strategy and the Environment, 26, 807-825. https://doi.org/10.1002/bse.1952 Gregory, A., Whittaker, J., \& Yan, X. (2016). Corporate social performance, 
competitive advantage, earnings persistence and firm value. Journal of Business Finance \& Accounting, 43(1-2), 3-30. https://doi.org/ 10.1111/jbfa.12182

Gurun, U. G., \& Butler, A. W. (2012). Don't believe the hype: Local media slant, local advertising and firm value. The Journal of Finance, 67(2), 561-598.

https://doi.org/10.1111/j.1540-6261.2012.01725.x

Hasseldine, J., Salama, A. I., \& Toms, J. S. (2007). Quantity versus quality: The impact of environmental disclosures on the repulation of UK Plcs. The British Accounting Review, 37, 231-248.

Hazelton, J. (2014). Corporate water accountability-The role of water labels given non-fungible extractions. Pacific Accounting Review, 26(1/ 2), 8-27.

https://doi.org/10.1108/PAR-07-2013-0074

Huang, R., \& Chen, D. (2015). Does environmental information disclosure benefit waste discharge reduction? Evidence from China. Journal of Business Ethics, 129(3), 535-552. https://doi.org/10.1007/s10551- 014-2173-0

Hurlimann, A., \& Dolnicar, S. (2012). Newspaper coverage of water issues in Australia. Water Research, 46(19), 6497-6507. https://doi.org/

10.1016/j.watres.2012.09.028

Islam, M. A., \& Deegan, C. (2010). Media pressures and corporate disclosure of social responsibility performance information: A study of two global clothing and sports retail companies. Accounting and Business Research, 40(2), 131-148.

https://doi.org/10.1080/00014788.2010. 9663388

Jo, H., \& Na, H. (2012). Does CSR reduce firm risk? Evidence from controversial industry sectors. Journal of Business Ethics, 110(4), 441-456.

https://doi.org/10.1007/s10551-012-1492-2

Jones, P., Hillier, D., \& Comfort, D. (2015). Water stewardship and corporate sustainability: A case study of reputation management in the food and drinks industry. Journal of Public Affairs, 15(1), 116-126. https://doi.org/10.1002/pa.1534

Kölbel, J. F., Busch, T., \& Jancso, L. M. (2017). How media coverage of corporate social irresponsibility increases financial risk. Strategic Management Journal, Online,DOI: https://doi.org/10.1002/smj, 38, 2266, 2284. 
Kurland, N. B., \& Zell, D. (2010). Water and business: A taxonomy and review of the research. Organization \& Environment, 23(3), 316-353.

https://doi.org/10.1177/1086026610382627

Lee, D. D., \& Faff, R. W. (2009). Corporate sustainability performance and idiosyncratic risk: A global perspective. The Financial Review, 44(2), 213-237. https://doi.org/10.1111/j.1540-6288.2009.00216.x

Li, D., Huang, M., Ren, S., Chen, X., \& Ning, L. (2016). Environmental legitimacy, green innovation, and corporate carbon disclosure: Evidence from CDP China 100. Journal of Business Ethics, 150, 1089-1104. https://doi.org/10.1007/s10551-016$3187-6$

Li, H., Fu, S., \& Gao, P. (2016). Media attention, carbon disclosure and corporate value. Statistical Research, 33(9), 63-69.

Li, Y. Q., Eddie, I., \& Liu, J. H. (2014). Carbon emissions and the cost of capital: Australian evidence. Review of Accounting and Finance, 13(4), 400-420. https://doi.org/10.1108/RAF-08-2012-0074 Lieberman, M. B., \& Asaba, S. (2006). Why do firms imitate each other? Academy of Management Review, 31(2), 366-385. https://doi.org/ 10.5465/amr.2006.20208686 Liu, B., \& McConnell, J. J. (2013). The role of the media in corporate governance: Do the media influence managers' capital allocation decisions? Journal of Financial Economics, 110(1), 1-17. https://doi. org/10.1016/j.jfineco.2013.06.003

Liu, J., \& Yang, W. (2012). Water sustainability for China and beyond. Science, 337(6095), 649-650. https://doi.org/10.1126/science.1219471 Ljungqvist, A., Zhang, L., \& Zuo, L. (2016). Sharing risk with the government: On the causal effects of taxes on corporate risk-taking. Journal of Accounting Research, 55(3):669-707. DOI: https://doi.org/10.2139/ ssrn.2705788, Forthcoming. Luo, L., \& Tang, Q. (2014). Does voluntary carbon disclosure reflect underlying carbon performance? Journal of Contemporary Accounting and Economics, 10, 191205. https://doi.org/10.1016/j.jcae.2014.08.003

Luo, X., \& Bhattacharya, C. B. (2009). The debate over doing good: Corporate social performance, strategic marketing levers, and firm- idiosyncratic risk. Journal of 
Marketing, 73(6), 198-213. https://doi. org/10.1509/jmkg.73.6.198

Mahadeo, J. D., Oogarah-Hanuman, V., \& Soobaroyen, T. (2011). Changes in social and environmental reporting practices in an emerging economy (2004-2007):

Exploring the relevance of stakeholder and legitimacy theories. International Journal of Earth Sciences, 35(4), 727-743.

Maignana, I., \& Ferrell, O. C. (2003). Nature of corporate responsibilities:

Perspectives from American, French, and German consumers. Journal of Business Research, 56(1), 55-67. https://doi.org/10.1016/S0148- 2963(01)00222-3

Martinez, F. (2015). A three-dimensional conceptual framework of corporate water responsibility. Organization \& Environment, 28(2), 137-159.

https://doi.org/10.1177/1086026614545632

McCombs, M. (2000). The agenda-setting role of the mass media in the shaping of public opinion. Unpublished manuscript. Available at:

https://www.infoamerica.org/documentos_pdf/mccombs01.pdf. Accessed: 29 Jan 2017.

McCombs, M. E., \& Shaw, D. L. (1972). The agenda-setting function of mass media. Public Opinion Quarterly, 36(2), 176-187. https://doi.org/ 10.1086/267990

McCombs, M. E., Shaw, D. L., \& Weaver, D. H. (2014). New directions in agendasetting theory and research. Mass Communication and Society, 17(6), 781-802. https://doi.org/10.1080/15205436.2014.964871

Mitchell, R. K., Agle, B. R., \& Wood, D. J. (1997). Toward a theory of stake- holder identification and science: Defining the principle of who and what really counts. Academy of Management Review, 22(4), 853-886.

https://doi.org/10.5465/amr.1997.9711022105

Morikawa, M., Morrison, J., \& Gleick, P. (2007). Corporate reporting on water -A review of eleven global industries. Oakland, California: Pacific Institute for Studies in Development, Environment, and Security.

Oikonomou, I., Brooks, C., \& Pavelin, S. (2012). The impact of corporate social performance on financial risk and utility: A longitudinal analysis. Financial Management, 41(2), 483-515. https://doi.org/10.1111/j. 1755-053X.2012.01190.x 
Orlitzky, M., \& Benjamin, J. D. (2001). Corporate social performance and firm risk: A meta-analytic review. Business \& Society, 40(4), 369-396.

https://doi.org/10.1177/000765030104000402

Poisson-de Haro, S., \& Bitektine, A. (2015). Global sustainability pressures and strategic choice: The role of firms' structures and non-market capabilities in selection and implementation of sustainability initiatives. Journal of World Business, 50(2), 326-341. https://doi.org/10.1016/j. jwb.2014.10.009

Pollach, I. (2014). Corporate environmental reporting and news coverage of environmental issues: An agenda-setting perspective. Business Strategy and the Environment, 23(5), 349-360. https://doi.org/ 10.1002/bse.1792

Pollock, T. G., \& Rindova, V. P. (2003). Media legitimation effects in the market for initial public offerings. Academy of Management Journal, 46(5), 631-642.

Qiu, Y., Shaukat, A., \& Tharyan, R. (2016). Environmental and social disclosures: Link with corporate financial performance. The British Accounting Review, 48(1), 102-116. https://doi.org/10.1016/j.bar.2014.10.007

Rajput, N., Kaura, R., \& Khanna, A. (2013). Water disclosure practices in Indian companies: A road less travelled. Research Journal of Social Science \& Management, $12(5), 132-144$.

Reig, P., Shiao, T., \& Gassert, F. (2013). Aqueduct water risk framework. Washington, D.C.: World Resources Institute.

Ross, S., Westerfield, R., \& Jordan, B. (2011). Essentials of corporate finance (7th ed.). Boston: McGraw-Hill Irwin.

Salama, A., Anderson, K., \& Toms, J. S. (2011). Does community and environmental responsibility affect firm risk? Evidence from UK panel data 1994-2006. Business Ethics: A European Review, 20(2), 192-204. https://doi.org/10.1111/j.14678608.2011.01617.x

Schembera, S. (2016). Implementing corporate social responsibility: Empirical insights on the impact of the UN global compact on its business participants. Business \& Society, 57(5), 783-825.

Signori, S., \& Bodino, G. A. (2013). Water management and accounting: Remarks 
and new insights from an accountability perspective. Studies in Managerial and Financial Accounting, 26(1), 113-159.

Spence, M. (1973). Job market signaling. Quarterly Journal of Economics, 87(3), 355-374. https://doi.org/10.2307/1882010

Starr, D. (2016). Just 90 companies are to blame for most climate change, this 'carbon accountant' says. Science. https://www.sciencemag.org/ news/2016/08/just-90companies-are-blame-most-climate-change- carbon-accountant-says Tetlock, P. C. (2011). All the news that's fit to reprint: Do investors react to stale information? Review of Financial Studies, 24(5), 1481-1512. https://doi.org/10.1093/rfs/hhq141

Tian, G. L., Feng, H., \& Yu, Z. B. (2016). The corporate governance role of media coverage in capital market (in Chinese). Accounting Research, 26 (06), 21-29. Tilling, M. V., \& Tilt, C. A. (2010). The edge of legitimacy: Voluntary social and environmental reporting in Rothmans' 1956-1999 annual reports. Accounting, Auditing \& Accountability Journal, 23(1), 55-81. https:// doi.org/10.1108/09513571011010600

Wang, J., \& Ye, K. (2015). Media coverage and firm valuation: Evidence from China. Journal of Business Ethics, 127(3), 501-511. https://doi. org/10.1007/s10551-0142055-5

Wei, J., Wang, H., Fan, J., \& Zhang, Y. (2013). Corporate accidents, media coverage, and stock market responses. Chinese Management Studies, 7(4), 617-630. https://doi.org/10.1108/CMS-09-2013-0171 Wintoki, M., Linck, J., \& Netter, J. (2012). Endogeneity and the dynamics of internal corporate governance. Journal of Financial Economics, 105(3), 581-606. https://doi.org/10.1016/j.jfineco.2012.03.005

Zhang, L.H., \& Tang, Q.L. (2015). Determinants of corporate voluntary water disclosure: A differentiation strategy focus. http://cms.mngt.waikato.ac. nz/Portals/113/papers/Zhang03C.pdf, Unpublished manuscript Zyglidopoulos, S. C., Georgiadis, A. P., Carroll, C. E., \& Siegel, D. S. (2012). Does media attention drive corporate social responsibility? Journal of Business Research, 
65(11), 1622-1627. https://doi.org/10.1016/j. jbusres.2011.10.021 